\title{
Az Európai Unió (szabályozási) útja a szuverenitás felé az adatalapú gazdaságban
}

\author{
The European Union's (Regulatory) Path to \\ Sovereignty in the Data-driven Economy
}

Az Európai Unió (EU) célja a digitális korban is az, hogy megőrizze értékeit, ezért a digitális kor kihivásainak megválaszolásakor is a saját útját kivánja járni. Az EU a digitális szuverenitás elérése egyik fö eszközének (a technológiai befektetések ösztönzése és támogatása mellett) az értékei mentén müködő szabályozást választotta. Lévén a digitális kor szabályozásának fó innovátora a világban, az EU egyik fö stratégiai kérdése a 21. században, hogy miként tudja visszaszerezni a kontrollt adatvagyona felett, csökkentve az adatok elvesztéséhez vezetô technológiai kiszolgáltatottságot. Ennek kapcsán megállapítható, hogy az ebben a körben született eddigi EU-s kezdeményezések a zéróáras üzleti modellel megvalósuló adatelszívást nem szoritanák keretek közé, emiatt viszont nem látszik, hogy az EU kitettsége ezen a téren csökkenne.

Kulcsszavak: adat, technológiai órások, digitális gazdaság szabályozása, digitális szuverenitás, versenyjog

The EU aims to preserve its values in the digital age, and therefore wants to follow its own way in tackling of the challenges of the digital age. The EU has chosen regulation as one of the main tools for achieving digital sovereignty and become the major innovator in the regulation of the digital age in the world. One of the key strategic challenges for the EU in the $21^{\text {st }}$ century is how it can regain control of its data assets. In this context, the EU initiatives taken so far would not limit the data flow to U.S. as a result of the zero-cost business model; therefore, the EU exposure in this field does not seem to be decreased.

Keywords: data, technology giants, digital economy regulation, digital sovereignty, competition law

A Gazdasági Versenyhivatal elnökhelyettese, a Versenytanács elnöke, tanszékvezető egyetemi docens.

E-mail: toth.andras@kre.hu 


\section{Bevezetés: az EU helye a globális adatalapú gazdaságban}

Az ENSZ adatai szerint a globális adatalapú gazdaság magasan koncentrált, a legnagyobb online platformok piaci kapitalizációja alapján az amerikai és kínai cégek 90\%-ot tesznek ki, ebből az amerikai vállalatok részesedése $70 \%$, miközben az európai cégek aránya nem éri el a 4\%-ot. ${ }^{1}$ Ezen adatok szerint az USA abszolút piacelső a blokklánc-technológia, a felhőszolgáltatások és a dolgok internete (IoT) terén, miközben például a felhő jelentősége a folyamatos adatbővülés fényében egyre nő. ${ }^{2} \mathrm{~A}$ felhőben tárolt európai adatok $80 \%$-át olyan öt nagyvállalat kezeli, amelyek között egyetlen európai sincs. Az első 20 globális technológiai vállalat között sincsen egyetlen európai sem. A mesterséges intelligenciába mint a jövő technológiájába való beruházás terén is megelőzi az EU-t (7\%) az USA és Kína is (együtt $80 \%){ }^{3}$ Az amerikai Google dominálja az EU-ban a keresőmotorok és a mobiltelefon operációs rendszerek piacát, a Facebook pedig meghatározó a közösségi média területén. ${ }^{4}$

Ha a digitális gazdaság legfontosabb alapanyagát, az adatokat nézzük, ${ }^{5}$ akkor megállapítható, hogy az európai adatok 92\%-át az USA-ban kezelik, amelyhez az amerikai kormányzati szerveknek hozzáférésük lehet. ${ }^{6} \mathrm{Ha}$ az adatok az új olaj, ${ }^{7}$ akkor természetesen, aki birtokolja őket, az jelentős hatalmat tudhat magának. ${ }^{8}$ Kína az adatvagyonát lényegében nemzeti stratégiai értéknek tekinti, teljes állami felügyelet érvényesül ezen a téren az egyéni jogok védelmének figyelmen kívül hagyásával, míg az USA-ban ezen a téren is a magánszféráé a döntő szerep, jelentős piaci koncentráltság mellett. ${ }^{9}$ Ezen amerikai technológiai óriások zéróáras (az ingyenesség látszatára építő) üzleti modellje az európai adatvagyont az USA-ba szívja, ${ }^{10}$ amely nem csak további üzletszerzésre használható fel. Az Európai Bíróság 2020 júliusában hozott ítélete ${ }^{11}$ is megerősíti ezeket az aggodalmakat. Ebben az ítéletében az Európai Bíróság kinyilvánította, hogy az EU-USA adatvédelmi pajzs keretrendszere már nem érvényes mechanizmus az EU

United Nations: Digital Economy Report 2019. 2019. 23

European Commission: Cloud computing (é. n.).

European Investment Bank - European Commission: Artificial intelligence, blockchain and the future of Europe. How disruptive technologies create opportunities for a green and digital economy (2021).

4 European Commission: Inception impact assessment on the Ex ante regulatory instrument, Ares(2020) 2877647 (2020. december 16.).

5 EDPS: Opinion 8/2016 EDPS Opinion on coherent enforcement of fundamental right since the age of big data (2016. szeptember 23.) 6.

6 Samuel Stolton: LEAK: Commission in bid for EU data sovereignty with digital decade targets. Euractive, 2021. március 8; Sean Fleming: What is digital sovereignty and why is Europe so interested in it? World Economic Forum, 2021. március 15.

The world's most valuable resource is no longer oil, but data. The Economist, 2017. május 6.

François Candelon - Martin Reeves: The New Digital World: Hegemony or Harmony? BCG, 2017. november 14.

9 European Commission: Communication from the Commission to European Parliament, European Council, the Council, the European Economic and Social Committee, the Committee of the Regions. A European strategy for data $\operatorname{COM}(2020) 66$ final (2020. február 19.) 3.

Stolton (2021): i. m.

Bővebben lásd: C-311/18, Data Protection Commissioner v Facebook Ireland Ltd ECLI:EU:C:2020:559.

Európai Tükör 2021/2. 
adatvédelmi követelményeinek való megfelelés érdekében, amikor személyes adatokat továbbítanak az Európai Unióból az Egyesült Államokba. Az Európai Bíróság szerint ugyanis nem biztosított az EU általános adatvédelmi rendelet $\left(\mathrm{GDPR}^{12}\right)$ és az EU Alapjogi Charta által személyes adatok vonatkozásában rögzített védelmi szint, mert az EU-adatok jogosultjainak nem áll rendelkezésre hatékony védelmi mechanizmus, ha az amerikai felhasználás sérti az EU jogában létező és elismert jogaikat, például az adataik amerikai kormányzati felhasználása esetén. Az európai adatvagyon USA-ba vándorlása többek között a mesterséges intelligencia (MI) kifejlesztése és felhasználása terén folytatott nagy nemzetközi versenyfutásban is károsnak bizonyult. ${ }^{13} \mathrm{Az}$ adatok ugyanis mennyiségi és minőségi szempontból is meghatározók az MI müködése szempontjából. ${ }^{14}$

Jelen tanulmányban azt mutatom be, hogy az Európai Unió milyen kihívásokkal szembesül a globális digitális gazdaságban és azoknak milyen szabályozási eszközökkel próbál megfelelni. Ennek kapcsán hangsúlyos, hogy a digitális kor szabályozása maga az Európai Unió útja az önálló hang megtalálása felé.

\section{Stratégiai megközelítések a globális digitális gazdaságban}

Az amerikai hozzáállás ugyanazzal a privatizált modellel jellemezhető a digitális gazdaságot illetően is, mint megannyi más gazdasági ág (például energetika, távközlés) esetében az USA-ban. ${ }^{15}$ Ezek az amerikai technológiai vállalatok az ingyenességre alapított üzleti modelljük segítségével óriási adatvagyonra tesznek szert. Kína inkább az ellenőrzés fenntartására, valamint a külső hatások és szereplők korlátozására összpontosít. A kormánynak joga van teljeskörűen ellenőrizni az internetet Kínában, beleértve a cenzúrát, és korlátozni a külföldi technológiai cégek piacra jutását. ${ }^{16}$ Kína globális vezetővé és szabványosítóvá akar válni az olyan következő generációs iparágak területén, mint a mesterséges intelligencia, a robotika és a félvezetők. Egyes vélemények

12 Az Európai Parlament és a Tanács (EU) 2016/679 rendelete (2016. április 27.) a természetes személyeknek a személyes adatok kezelése tekintetében történő védelméről és az ilyen adatok szabad áramlásáról, valamint a 95/46/EK rendelet hatályon kívül helyezéséről (általános adatvédelmi rendelet: GDPR). Tóth András: A mesterséges intelligencia szabályozásának paradoxonja és egyes jogi vonatkozásainak alapvető kérdései. Infokommunikáció és Jog, (2019), 2. 3-9; European Commisson: Communication from the Commission to European Parliament, European Council, the Council, the European Economic and Social Committee, the Committee of the Regions on Artificial Intelligence for Europe COM(2018) 237 final (2018. április 25.) 1.

14 Az MI megbízható múködése szempontjából kritikus, hogy az adatok teljes körűek és relevánsak legyenek, különben fennáll az emberi jogok sérülésének veszélye (diszkrimináció, egészség) lásd European Commission: White Paper on Artificial Intelligence - A European approach to excellence and trust $\operatorname{COM}(2020) 65$ final (2020. február 19.). 19.

15 Marietje Schaake: How democracies can claim back power in the digital world. MIT Technology Review, 2020. szeptember 29.

16 Rachel F. Fefer: EU Digital Policy and International Trade. Congressional Research Service R46732, 2021. március 25 .

Európai Tükör 2021/2. 
szerint Kína olyan új internetes szabványokban érdekelt, amelyek felváltják a globális, nyitott, interoperábilis szabványokat, annak érdekében, hogy ezzel segítse elő az állami ellenőrzés gyakorlását. ${ }^{17}$ Emiatt az EU és az Egyesült Államok 2021 nyarán együttműködésről döntött a feltörekvő technológiákkal kapcsolatos közös szabványok terén. Az Európai Parlament 2019-ben állásfoglalást fogadott el ${ }^{18}$ az egyre növekvő kínai technológiai jelenléthez kapcsolódó biztonsági fenyegetésekről, valamint az ezek csökkentésére irányuló lehetséges uniós szintű intézkedésekről. A Parlament mély aggodalmának adott hangot a közelmúltbeli állítások miatt, miszerint a kínai vállalatok által kifejlesztett 5G készülékek olyan hátsó ajtókat tartalmazhatnak, amelyek lehetővé tennék a gyártók és a hatóságok számára az EU-ból származó magán- és személyes adatokhoz való jogosulatlan hozzáférést.

Az EU történelmileg sokkal inkább alapoz a szabályozásra, mint az USA. ${ }^{19} \mathrm{Az}$ EU célja a digitális korban is az, hogy megőrizze értékeit, a digitális kor kihívásainak megválaszolásakor is a saját útját kívánja járni. ${ }^{20}$ Ennek egyik legmarkánsabb megjelenése pedig a szabályozás. Ez az oka annak, hogy a digitális gazdaság szabályozásában az EU élen jár, annak egyértelmú modellalkotója ${ }^{21}$ és innovátora. ${ }^{22}$ Például a GDPR számos más ország adatvédelmi jogát inspirálta, ${ }^{23}$ és az EU Bizottság tette le az asztalra a világ első mesterségesintelligencia-szabályozási javaslatát. ${ }^{24} \mathrm{Az}$ EU digitális világot szabályozó kezdeményezései sok esetben a jogi akadémiai kutatásokat is megelőzik, amely mindenképpen figyelemre méltó fejlemény. Bár Tirole szerint ${ }^{25}$ a szabályozás implementálása valóban lassú és a technológiai folyamatok sokszor gyorsabbak nála, a szabályozási kezdeményezések terén azonban úgy tűnik, az EU intézményei megelőzik az akadémiai szférát. Ez is azzal magyarázható, hogy ez a terület kifejezetten gyorsan változó, és az olyan nagy intézmények (mint az EU) hatékonyabban és gyorsabban tudják lekövetni a jogi folyamatokat, mint az akadémiai kutatók, akiknek ebben a körben mára alapvetően az EU-s szabályozási javaslatok utólagos értékelése és nem de lege ferenda alakítása maradt.

Mark Scott - Jacopo Barigazzi: US and Europe to forge tech alliance amid China's rise. Politico, 2021. június 9.

18 European Parliament: Security threats connected with the rising Chinese technological presence in the EU and possible action on the EU level to reduce them (2019. március 12.).

19 Konstantinos Komaitis - Justin Sherman: US and EU tech strategy aren't as aligned as you think. Brookings Tech Stream, 2021. május 11.

20 Európai Bizottság: A Bizottság Közleménye az Európai Parlamentnek, a Tanácsnak, az Európai Gazdasági és Szociális Bizottságnak és a Régiók Bizottságának: Európa digitális jövőjének megtervezése COM(2020) 67 végleges (2020. február 19.).

21 European Commission: Shaping Europe's digital future (é. n.).

22 Dave Keating: Why the EU leads in digital regulation, but lags in digital innovation. 2019. október 23.

23 Jennifer Bryant: 3 years in, GDPR highlights privacy in global landscape. IAPP, 2021. május 25.

24 European Commission: Europe fit for the Digital Age: Commission proposes new rules and actions for excellence and trust in Artificial Intelligence (2021. április 21.).

25 Jean Tirole: Competition and the Industrial Challenge for the Digital Age. 2020. április 3. 


\section{Az EU legnagyobb kihívása a digitális szuverenitás elérése}

Európa legfőbb kihívása a technológiai függés csökkentése az USA-tól és Kínától. ${ }^{26} \mathrm{Az}$ EU digitális szuverenitása ezért kulcskérdés. ${ }^{27}$ Bár az EU Bizottság hangsúlyozza, hogy a digitális szuverenitása biztosítása nem mások ellen irányul, a globális versenytársak reakcióiból látszik, hogy a világ digitalizálódása kapcsán is zajlik a hatalmak helyezkedése. Trump és Obama is elítélték az amerikai technológiai cégekkel szembeni európai fellépést. ${ }^{28}$ Legújabban pedig az EU Bizottság Digital Market Act (DMA) javaslata ${ }^{29}$ kapcsán fogalmazta meg az amerikai kormányzat aggodalmát amiatt, hogy a javaslat alapvetően a technológiai óriásokat célozná. ${ }^{30}$

A kínai cégeknek az európai 5G infrastruktúra fejlesztésében játszott szerepe, valamint az amerikai technológiai óriások európai adatelszívása is azt mutatja, hogy az európai adatvagyon a 21. századi digitális világgazdaság hegemóniaharcának középpontjába került. Ebben nincs újdonság, hiszen a történelemben hegemóniára mindig más népek erőforrásainak felhasználásával lehetett legkönnyebben eljutni. Ennek eszköze lehet a háború, gyarmatosítás, rabszolga-kereskedelem, vagy békeidőben a tőke, az emberek és újabban pedig az adatok elszívása. Az EU-t ebben a hegemóniaharcban a periféria védekezőreflexe jellemzi. ${ }^{31}$

$\mathrm{Az}$ EU digitális szuverenitása visszanyerésének egyik fő eszközéül (a technológiai befektetések ösztönzése és támogatása mellett) az értékei mentén működő szabályozást választotta. Az EU Bizottság 2019-2024 közötti stratégiájának prioritásai között szerepel az EU digitális korra való felkészítése, melynek fókuszában az embereket szolgáló technológiák, a tisztességes verseny és a nyílt Internet áll. ${ }^{32}$ Ennek biztosítása érdekében a Bizottság több olyan szabályozási intézkedést is felsorol, amelyek hozzájárulhatnak az EU digitális szuverenitásának a növeléséhez: kiberbiztonság, adóztatás, technológiai óriások piaci dominanciája elleni küzdelem, adatok védelme és elérhetővé tétele, gazdasági nyitottság csökkentése, mesterséges intelligencia fejlesztése, az internet nyitottságának biztosítása. Az alábbiakban ezen intézkedéseket és eredményességüket tekintjük át röviden.

\footnotetext{
$26 \quad$ Komaitis-Sherman (2021): i. m.

$27 \quad$ Fleming (2021): i. m.

28 David M. Herszenhorn - Maia De La Baume: Trump slammed her as a U.S. hating 'tax lady'. She just got a promotion. Politico, 2019. november 27.; James Vincent: Obama accuses EU of attacking American tech companies because it ,can't compete'. The Verge, 2015. február 17.; Daniel Bunn: The U.S. Trade Representative Expands Its Digital Services Tax Investigations. Tax Foundation, 2020. június 2.

29 Proposal for a Regulation of the European Parliament and of the Council on contestable and fair markets in the digital sector (Digital Markets Act) COM(2020) 842 final (2020. december 15.) 2020/0374.

so Javier Espinoza - James Politi: US warns EU against anti-American tech policy. Financial Times, 2021. június 15.

$31 \quad$ Egresi Katalin et al.: Államelmélet. Győr, Széchenyi István Egyetem, 2016. 247.

$32 \quad \operatorname{COM}(2020) 67$ végleges.
} 


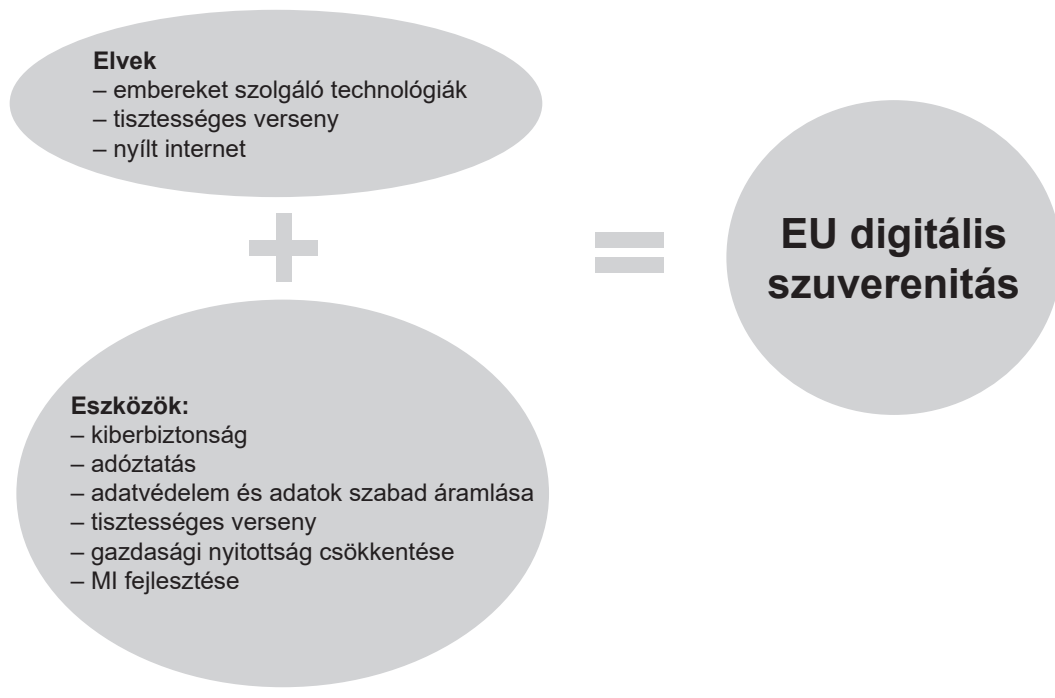

1. ábra

Az EU digitális szuverenitási stratégiájának elemei

Forrás: a szerző szerkesztése

\subsection{Digitális adó}

Miközben az amerikai technológiai óriások jelentős gazdasági, társadalmi változásokat indítottak el az EU-ban, addig a közterhek viseléséhez nem feltétlenül járulnak hozzá abban az országban, ahonnan a bevételeik megteremtéséhez szükséges adatvagyon származik. Márpedig, ha az adat az új olaj, akkor az analógia csak úgy helyes, ha közben azok az államok is profitálnak belóle, amelyek területén azt kiaknázták. ${ }^{33}$ A nagy multinacionális vállalatok (mint amilyenek a technológiai óriások is) eleve hozzáférnek azokhoz a kreatív adózási tanácsokhoz, amelyek segítik őket az adó optimalizálásában. Az OECD 2018. évi becslése alapján a világ összes országát tekintve a kormányzatok éves bevételkiesése 2015-ben legalább 100-240 milliárd dollár volt, ami a globális társasági adóbevétel 4-10\%-ának felel meg. ${ }^{34}$ Ismert a „dupla ír” vagy a „holland szendvics” példája: csak egy ír leánycég kell, aki elutalta a bevételt egy holland, még munkavállalókat sem foglalkoztató társaságnak, amely visszautalta egy ír tulajdonú offshore cégnek. ${ }^{35}$ Továbbá a digitális szektor jellemzői tovább könnyítik az adókijátszást. A jelenlegi adószabályok százévesek és ezért a fizikai jelenléten alapulnak, így a fizikai jelenlét biztosít lehetőséget

33 Rigó Csaba Balázs - Tóth András: A digitális szolgáltatási adó szimbolikus jelentősége és annak gyakorlati következményei. Pénzügyi Szemle, 65. (2020), 4. 516-530.

OECD: What is BEPS? (é. n.).

Jonathan Tepper - Denise Hearn: The Myth of Capitalism. Monopolies and the Death of Competition. Wiley, 2019. 93. 
az országok adóztatási jogkörének gyakorlására. ${ }^{36}$ A digitális szolgáltatást nyújtó világcégek működésbeli jellemzőikből fakadóan azonban tényleges fizikai jelenlét nélkül is képesek adott országban szolgáltatást nyújtani, illetve az ott megtermelt hozzáadott érték segítéségével nyereségre szert tenni. E digitális szolgáltatást nyújtó világcégek tehát még könnyebben kerülik meg a helyi adófizetési kötelezettségeket, mint az amúgy ebből a szempontból eleve kreatív multinacionális társaságok. Miközben a nemzeti cégek és KKV-k megfizetik az adókat, addig ezek a digitális szolgáltatást nyújtó világcégek évente 60 milliárd euró adó megfizetését kerülik el. ${ }^{37} \mathrm{Az}$ Európai Bizottság szerint a digitális szolgáltatást nyújtó vállalatok adóterhelése a fele a hagyományos vállalatokénak, ami csak tovább növeli a feszültségeket. ${ }^{38}$ A digitális szolgáltatási adó azonban 2019-ben éppen annak az Írországnak a vétóján bukott el, aki legtöbbet profitál abból, hogy az amerikai digitális óriások rajtuk keresztül telepednek le az EU-ban. ${ }^{39}$ Tørsløv és társai ${ }^{40}$ becslései szerint a technológiai óriások 2017-ben 126 milliárd euró nyereséget termeltek Írországban, 79 milliárd eurót Hollandiában és 66 milliárd eurót Luxemburgban, így Írország egyértelműen az adóoptimalizálás elsődleges helye az EU-ban. Írország társasági adóbevételeinek $67 \%$-át az országban letelepedett vállalatok nyereségéből nyeri. ${ }^{41}$ Ezzel szemben számos tagállam az elbukott EU-s javaslat ${ }^{42}$ mentén a technológiai óriások megadóztatásáról döntött, felvállalva az amerikai kereskedelmi fenyegetések kockázatát is. ${ }^{43}$

\subsection{Kiberbiztonság}

A kiberbiztonság terén a 2018-ban elfogadott európai kiberbiztonsági törvény ${ }^{44}$ az EU egészére kiterjedő kiberbiztonsági tanúsítási keretrendszert vezetett be. Mivel az EU-ban számos különféle biztonsági tanúsítási rendszer létezett, ezért az EU-szerte érvényes kiberbiztonsági tanúsítványok közös keretrendszere nélkül egyre nagyobb volt a széttöredezés veszélye. Az EU-szintű kiberbiztonsági tanúsítási keretrendszer megteremtését úgy lehet tekinteni, mint amely révén az EU megkezdte a kiberbiztonság terén

36 Állami Számvevőszék: Elemzés a digitális gazdaság megadóztatásának aktuális kérdéseirôl, a modern gazdasághoz illeszkedő új uniós adószabályokról értékelő elemzés figyelemmel a terület ellenörizhetöségére (2020. március 5.).

37 Tepper-Hearn (2019): i. m. 93.

38 European Commission: Questions and Answers on a Fair and Efficient Tax System in the EU for the Digital Single Market (2018. március 21.).

39 Jorge Valero: The EU's digital tax is dead, long live the OECD's plans. Euractive, 2019. március 8.

40 Thomas Tørsløv - Ludvig Wier - Gabriel Zucman: The Missing Profits of Nations: 2017 Figures. 2019; Paul Twomey: Addressing Market Failures to improve the health of the Digital Infrastructure. T20 Policy Brief, 2017.

41 Niclas Frederic Poitiers - Dennis Görlich: Geopolitical Aspects of Digital Trade. European Union, 2020. 20.

42 Javaslat a Tanács Irányelve az egyes digitális szolgáltatások nyújtásából származó bevételek után fizetendő digitális szolgáltatási adó közös rendszeréről \{SWD(2018) 81\} - \{SWD(2018) 82\} Brüsszel, 2018.3.21. COM(2018) 148 final 2018/0073 (CNS).

43 Erről részletesen lásd Rigó-Tóth (2020): i. m.

44 Regulation (EU) 2019/881 of the European Parliament and of the Council of 17 April 2019 on ENISA (the European Union Agency for Cybersecurity) and on information and communications technology cybersecurity certification and repealing Regulation (EU) No 526/2013 (Cybersecurity Act).

Európai Tükör 2021/2. 
a szabványosítást, hiszen minden EU-ban tevékenykedő vállalatnak meg kell majd az EU elvárásainak felelnie. ${ }^{45} \mathrm{Az}$ EU kiberbiztonsági stratégiáját 2020 végén fogadták el, amely szerint az EU technológiai szuverenitását az összes internetre kapcsolódó szolgáltatás és termék ellenállóképességére kell alapozni. ${ }^{46} \mathrm{~A}$ stratégia a nagyobb kibertámadások megválaszolására EU-szintű kollektív képesség kiépítését javasolja. A Joint Cyber Unit platformként múködik majd az uniós szintű összehangolt reagálás biztosítására a nagyszabású kiberesemények alkalmával, valamint segítséget nyújt a támadásokból való kilábaláshoz.

\subsection{Mesterséges intelligencia szabályozása}

A mesterséges intelligencia (MI) terén az EU Bizottság 2021 áprilisában benyújtotta a világ első szabályozási javaslatát. ${ }^{47}$ A Bizottság e szabályozási javaslatában - lényegében követve az úgynevezett ismeretlen technológiák szabályozásának elméleti irányvonalát ${ }^{48}$ - kockázatalapú megközelítést fogadott el a mesterséges intelligencia vonatkozásában. Az MI egyik kihívást jelentő fontos jellemzője ugyanis az előreláthatóság fogalmához kapcsolódik. ${ }^{49}$ Alapvető különbség az emberek és az MI döntéshozatali folyamata között, hogy az emberi agy kognitív korlátoktól terhes azáltal, hogy nem képes elemezni az összes információt a rendelkezésre álló időkeretben. Ezért az emberek gyakran az optimális megoldás helyett kielégítő megoldás megtalálására törekszenek. ${ }^{50}$ $\mathrm{Az}$ MI ezzel szemben sokkal több lehetőséget tud áttekinteni egy adott időtartamon keresztül, mint egy ember, olyanokat is, amelyekkel az ember esetleg nem is számolt. Ebből fakad az MI úgynevezett feketedoboz-hatása, vagyis amikor az MI még a tervezői számára is meglepő vagy akár nem is értelmezhető eredménnyel áll elő. ${ }^{51} \mathrm{Az}$ ismeretlen technológiák a joggal szemben kettős elvárást támasztanak: egyrészről biztosítani kell, hogy a technológiai fejlődés ne ássa alá az emberi szabadságjogokat. Másfelől szükséges azonban az is, hogy a jog ne korlátozza a technológiai fejlődést. Az ismeretlen technológiára adott felelős jogi válasz kulcsa ebből következően egy olyan alapállás, amely a kockázatokat nem pusztán feltételezi, hanem azok létéről tudományos alapon

$45 \quad$ Tambiama Madiega: Digital sovereignty for Europe. European Parliamentary Research Service, PE 651.992. 2020. július. 4.

46 https://digital-strategy.ec.europa.eu/en/policies/cybersecurity-strategy

47 Az Európai Bizottság javaslata: Az Európai Parlament és a Tanács rendelete a mesterséges intelligenciára vonatkozó harmonizált szabályok (a mesterséges intelligencia törvény) megállapításáról és egyes Uniós jogalkotási aktusok módosításáról (2021. április 21.) COM(2021) 206 végleges 2021/0106(COD) \{SEC(2021) 167 végleges\} - \{SWD(2021) 84 végleges\} - \{SWD(2021) 85 végleges\}.

48 errôl részletesen lásd Tóth (2019): i. m.

49 Matthew U. Scherer: Regulating Artificial Intelligence Systems: Risks, Challenges, Competencies, and Strategies. Harvard Journal of Law \& Technology, 29. (2016), 2. 363.

$50 \quad$ Scherer (2016): i. m. 364.

51 Scherer (2016): i. m. 365; European Commission: Commission Report on safety and liability implications of AI, the Internet of Things and Robotics COM(2020) 64 final (2020. február 19.) 15. 
meggyőződik (precaution principle). ${ }^{52} \mathrm{Az}$ elővigyázatosság elve szerint az ismeretlen technológia blokkolható addig, amíg nem bizonyosodik be róla, hogy biztonságos. ${ }^{53}$ Ezt úgy kell érteni, hogy a tudományos bizonyítékok fényében a technológiával kapcsolatos kockázatok szabályozási elvárásokkal leszoríthatók-e egy még vállalható szintre. E szabályozási kockázatkezelés jegyében különbözteti meg a Bizottság MI-törvényjavaslata a mesterséges intelligenciákat az általuk jelentett kockázat mértéke szerint. Az elfogadhatatlan szintű kockázatot jelentő MI-k az uniós polgárok számára egyértelmű fenyegetést jelentenek, amelyek abszolút tilalom alá kell essenek, például a kormányzat által alkalmazott társadalmi pontozás, vagy a gyermekek veszélyes viselkedését ösztönző hangvezérelt játékok. A magas kockázatú MI-k forgalomba hozatalát megelőző és egész életciklusukra kiterjedő alapos értékelés alá kell vetni. Az EU Bizottság javaslata szerint a magas kockázatú MI-k:

- kritikus infrastruktúrák (például közlekedés), amelyek veszélyeztethetik a polgárok életét és egészségét;

- termékek biztonsági elemei (például MI-alkalmazás robot által segített mútétnél);

- foglalkoztatás (például önéletrajz-válogató szoftver);

- alapvető magán- és közszolgáltatások (például hitelpontozás, amelynek eredményeként a polgárok hiteltől eshetnek el);

- bűnüldözés, amely érintheti az emberek alapvető jogait (például a bizonyítékok megbízhatóságának értékelése).

A magas kockázatú mesterséges intelligenciának megfelelőség-ellenőrzésre, regisztrációra van szüksége és tanúsítvánnyal kell rendelkeznie. Amint az MI a piacon van, a hatóságok felelnek a piacfelügyeletért, a felhasználók biztosítják az emberi kontrollt, míg a gyártók forgalomba hozatal utáni monitoringrendszert működtetnek. A szolgáltatók és a felhasználók a súlyos eseményekről és meghibásodásokról pedig beszámolnak.

Korlátozott kockázatú mesterségesintelligencia-rendszer, mint például a csevegőrobot, minimális átláthatósági kötelezettségek hatálya alá tartozna a javaslat szerint, ami lehetővé teszi, hogy a felhasználó tájékozott döntést hozhat arról, hogy folytatja vagy kilép az alkalmazás használatából.

Minimális kockázatú például a MI-vel támogatott videójáték vagy spamszűrő. A Bizottság szerint az MI-rendszerek túlnyomó többsége ebbe a kategóriába tartozik majd, amelyre a javasolt szabályozás nem vonatkozna, mivel ezek a rendszerek csak minimális mértékben vagy egyáltalán nem jelentenek kockázatot az állampolgárok jogai vagy biztonsága szempontjából.

$52 \quad$ Az EU környezetvédelmi politikája a Riói Nyilatkozatra való hivatkozással szentesítette ezt az elvet, eszerint amikor komoly és visszafordíthatatlan károkozás veszélye áll fenn, akkor a teljes tudományos bizonyosság hiánya nem lehet az oka a környezetszennyezést megakadályozó költséghatékony intézkedések alkalmazásának. Esther Versluis et al.: Calculable Risks? An Analysis of the European Seveso Regime. In Morag Goodwin - Bert-Jaap Koops - Ronald Leenes (szerk.): Dimension of Technology Regulations. Wolf Legal Publishers, 2010. 264.

53 Jonathan B. Wiener: The regulation of technology, and the technology of regulation. Technology in Society, 26. (2004), 495. 


\subsection{A technológiai óriások dominanciája elleni küzdelem}

Jelenleg a Facebook ellen vizsgálódik az EU Bizottság ${ }^{54}$ és a német versenyhatóság ${ }^{55}$ is adat-kizsákmányolás miatt (emlékezetes: a tárgyban már született hasonló ügyben német döntés a Facebookkal szemben). ${ }^{56} \mathrm{Az}$ üzletfelek adatainak vertikális versenyben való tisztességtelen, versenyelőnyt keletkeztető felhasználása miatt az EU Bizottság előtt az Amazon, ${ }^{57}$ Facebook ${ }^{58}$ és Google ${ }^{59}$ ellen van folyamatban eljárás. Ön-preferencia miatt vizsgálja az EU Bizottság ${ }^{60}$ és az olasz versenyhatóság ${ }^{61}$ is az Amazont, miután a Google-t az EU Bizottság már elmarasztalta hasonlóért (lásd a korábban már hivatkozott Google Shopping ügyet). A Google, az Apple és az Amazon ellen azért folyik további EU Bizottsági eljárás, mert felmerült, hogy az érintett cégek korlátozzák más hangvezérelt asszisztensek elérését az eszközeiken. ${ }^{62} \mathrm{Az}$ Apple ellen ezen kívül két további Bizottsági eljárás van folyamatban, egyrészt az alkalmazás-áruházának szerződési feltételei, ${ }^{63}$ másrészt az Apple Play kizárólagos használatának előírása miatt. ${ }^{64}$ De szép számmal találunk a technológiai óriásokkal szemben tagállami versenyjogi eljárásokat is. Az olasz versenyhatóság az Enel elektromos autó appjának Google Autóból való kizárásáért büntette a Google-t erőfölénnyel való visszaélés miatt. ${ }^{65}$ A Google-t a francia versenyhatóság is megbírságolta erőfölénnyel való visszaélésért amiatt, mert saját reklámértékesítő piacterét részesítette előnyben. ${ }^{66} \mathrm{Az}$ Európai Bizottság 2021. június 22-én indított ugyanígy ebben a körben a Google online reklámértékesítési gyakorlatának vizsgálatára eljárást. ${ }^{67}$ De a Google-t vizsgálja a brit versenyhatóság is a harmadik felek cookie-jainak eltávolítása miatt. ${ }^{68}$

$54 \quad$ Lydia Beyoud - Aoife White: Facebook's Libra Currency Gets European Union Antitrust Scrutiny. Bloomberg, 2019. augusztus 20.

55 Bundeskartellamt: Bundeskartellamt examines linkage between Oculus and the Facebook network (2020. december 10.)

56 Bundeskartellamt (2020): i. m.

57 European Commission: Antitrust: Commission opens investigation into possible anti-competitive conduct of Amazon (2019. július 17.).

58 European Commission: Antitrust: Commission opens investigation into possible anticompetitive conduct of Facebook (2021. június 4.).

59 Javier Espinoza: Brussels asks news groups to describe their data deals with Google. Financial Times, 2019. december 9.

60 European Commission: Antitrust: Commission sends Statement of Objections to Amazon for the use of non-public independent seller data and opens second investigation into its e-commerce business practices (2020. november 10.).

61 Thibault Larger: Italy competition watchdog opens probe into Amazon, adding to EU list. Politico, 2019. április 16.

62 Foo Yun Chee: EU regulators to probe Alexa, Siri and other voice assistants. Reuters, 2020. július 16.

63 Apple investigated in UK over 'unfair' App Store claims. BBC, 2021. március 4.

64 European Commission: Antitrust: Commission opens investigations into Apple's App Store rules (2020. június 16.).

65 Italy fines Google for excluding Enel e-car app from Android Auto. Reuters, 2021. május 13.

66 Autorité de la concurrence: The Autorité de la concurrence hands out a $€ 220$ millions fine to Google for favouring its own services in the online advertising sector (2021. június 7.).

67 European Commission: Antitrust: Commission opens investigation into possible anticompetitive conduct by Google in the online advertising technology sector (2021. június 22.)

68 CMA opens investigation into possible abuse of dominance arising from Google's "Privacy Sandbox" browser changes. Practical Law, 2021. január 8. 
Fenti versenyügyi eljárások kifejezetten az elmúlt egy-két év hozadékai. A versenyhatóságokat több bírálat is érte amiatt, hogy évekig tétlenül nézték a technológiai óriások növekedését. 2009-2018 között a Google, az Apple, a Facebook és az Amazon 400 fúziót hajtott végre, miközben egyet sem tiltottak meg ezek közül. ${ }^{69} \mathrm{Az}$ EU első komolyabb fellépésére is csak 2017-ben került sor, ${ }^{70}$ igaz egyes vélemények szerint ezek a kezdeti versenyügyek (Google Shopping és Google Android ügy) ${ }^{71}$ inkább marginális és nem a problémák középpontjában álló kérdésekre vonatkoztak. ${ }^{72} \mathrm{Az}$ EU-ban viszont az amerikaihoz hasonló módon nem kérdőjeleződött meg a versenyjog hatályos érvényesülési koncepciója (lásd hipszter antitröszt). ${ }^{73}$ Ugyannakor az EU-ban is felmerült annak kérdése, hogy a versenyjog szabályainak, illetve alkalmazási tesztjeinek módosításával, ${ }^{74}$ akár erőteljesebb versenyjogi beavatkozással (például feldarabolás), ${ }^{75}$ radikálisabb versenyjogi kötelezettségek alkalmazásával, ${ }^{76}$ vagy versenyjogot meghaladó szabályozással lehetne-e még hatékonyabban fellépni a technológiai óriásokkal szemben. ${ }^{77} \mathrm{Ez}$ a vita az EU-ban a DMA-javaslattal a versenyjogot meghaladó szabályozás szükségessége javára eldőlni látszik.

A technológiai óriásokkal szembeni fenti számos eljárás önmagában elég erős jelzés arra vonatkozóan, hogy a versenyügyeknek önmagukban nincsen elégséges visszatartó erejük. Az ex-post beavatkozással elérhető elrettentés ilyenkor nem képes hatékonyan visszatartani a jogsértéstől, és kikényszeríteni a jogkövető magatartást. A Nobel-díjas Tirole szerint az óriáscégeket nem rendíti meg az erőfölénnyel való visszaélés miatt rájuk kiszabott bírság és nem tartanak a jó hírnevük sérelmétől sem. ${ }^{78} \mathrm{~A}$ DMA-javaslat ${ }^{79}$

$69 \quad$ Unlocking Digital Competition. Report of the Digital Competition Expert Panel. 2019. 84.

70 Commission Decision of 27.6.2017 relating to proceedings under Article 102 of the Treaty on the Functioning of the European Union and Article 54 of the Agreement on the European Economic Area (AT.39740 - Google Search [Shopping]).

71 Commission Decision of 18.7.2018 relating to a proceeding under Article 102 of the Treaty on the Functioning of the European Union (the Treaty) and Article 54 of the EEA Agreement (AT.40099 - Google Android).

72 Ződi Zsolt: Az USA Igazságügyi Minisztériumának keresete a Google ellen - a versenyjog dilemmái a platformgazdaságban. Gazdaság és Jog, 28. (2020), 10. 6-8.

73 Gönczöl Tünde: A hipszter antitrösztirányzat és kritikusai. In Valentiny Pál - Nagy Csongor István - Berezvai Zombor (szerk.): Versenyés Szabályozás 2018. Budapest, MTA KRTK Közgazdaság-tudományi Intézet, 2019. 13-43.

74 Például ha az algoritmusok olyan piacokon is megkönnyítik az összejátszást, amelyek nem felelnek meg az oligopolisztikus interdependencia tesztnek, akkor módosítani kell ezeket. Sebastian Felix Janka - Severin Benedict Uhsler: Antitrust 4.0 - the rise of Artificial Intelliegence and emerging challenges to antitrust law. European Competition Law Review, 39. (2018), 3. 112.

75 Jacob Parry: MEPs push for rules that allow EC to 'breakup' offenders - IMCO. 2021. január 28.; Adi Robertson: European lawmakers asked Mark Zuckerberg why they shouldn't break up Facebook. The Verge, 2018. május 22.

76 Michal Gal - Nicolas Petit: Radical Restorative Remedies for Digital Markets. Berkeley Technology Law Journal, 37. (2021), 1.; Ezt megelőzően Glen Weyl és Eric Posner már a létező szabályozási keretek innovatív felhasználása és nem újak létrehozása mellett érvelt a fogyasztói károk csökkentése érdekében a digitális piacokon: Eric A. Posner - E. Glen Weyl: Radical Markets. Princeton University Press, 2018. Unlocking Digital Competition. i. m.

78 Jean Tirole: Telecommunications and competition. In Pierre Buigues - Patrick Rey (szerk.): The Economics of Antitrust and Regulation in Telecommunications. Edward Elgar Publishing, 2004.

$79 \operatorname{COM}(2020) 842$ végleges 2020/0374. 
indokolása kifejezetten elismeri, hogy a versenyjogi érvényesítés utólag történik, és gyakran nagyon összetett tények kiterjedt, eseti alapú vizsgálatát igényli. ${ }^{80}$

Az EU-ban a digitális gazdaság versenyproblémái kapcsán maguk a versenyhatóságok (ideértve az EU Bizottságot, amelynek 2019-től a digitális korszakért felelős ügyvezető alelnöke egyben az EU versenyügyi biztosa is) azok, amelyek a technológiai óriások szabályozás alá vonását sürgetik úgy, hogy az új hatáskörök gyakorlására magukat ajánlják. A Benelux-államok versenyhatóságainak közös nyilatkozata ${ }^{81}$ és a francia versenyhatóság javaslata ${ }^{82}$ is a versenyhatóságok digitális óriásokkal szembeni szabályozási megerősítése mellett érvelt. A 2021-ben elfogadott német szabályozás pedig már fel is jogosította a német versenyhatóságot a digitális kapuőrökkel szembeni fellépésre. ${ }^{83}$ A brit $\mathrm{CMA}^{84}$ a versenyhatóságon belüli dedikált szervezeti egység létrehozását javasolta versenyjogot kiegészítő további eszközök megteremtése mellett. A DMA-javaslat kapcsán is az EU versenyhatóságai közös nyilatkozatban kérik, hogy a DMA alkalmazásában (a kapuőri kijelölés és a mentesítés kivételével) kapjanak ők is szerepet az 5. és 6. cikkbe ütköző magatartásokkal szembeni fellépés formájában. ${ }^{85}$ Miközben tehát a versenyhatóságokat bírálatok érték amiatt, hogy a technológiai óriások a szemük láttára és némely esetben az asszisztálásuk mellett nőttek nagyra, addig az EU-ban a versenyhatóságok a technológiai óriások megregulázásának zászlóvivői és úgy tűnik, az új hatáskörök élvezői is lesznek. Mindenképpen figyelemre méltó fejlemény, hogy az EU-ban a versenyhatóságok ilyen értelemben megerősödve kerülnek ki a kritikákból.

$\mathrm{Az}$ adatalapú online platformpiacokon a méretgazdaságosság és hálózati hatás kombinációja egyetlen vállalkozás javára billentheti az egész piacot (tipping), amikor a verseny a piacért, és már nem a piacon folyik. ${ }^{86}$ Ebben az esetben a piaci hatalom tartósan is fennállhat, miként a technológiai óriások példája is mutatja. Emiatt az ilyen innovatív piacokon az új piacra lépők fontos szereplők, hiszen számukra is az innováció biztosítja a profitábilis piacralépési képességet. ${ }^{87}$ Ezért az új belépők előtt a piacot a belépés szempontjából szabaddá kell tenni, már ami az üzletfelekhez és fogyasztókhoz való hozzáférést illeti. Ezért hangsúlyozza a Nemzetközi Valutaalap (IMF) is, hogy a digitális piacokon az interoperábilitás biztosítása és az adathordozhatóság a verseny élénkítésének fontos eszköze, ${ }^{88}$ és ezekkel a DMA-javaslat is számol. A DMA a piac-megtámadhatóságát a felhasználók és üzletfelek alternatív választási lehetőségeinek és autonomiájának szélesítésével kívánja elérni. ${ }^{89}$

COM(2020) 842 végleges 5. preambulum-bekezdés.

Belgian Competition Authority, Dutch Authority for Consumers \& Markets, and Luxembourg Conseil de la Concurrence, Joint memorandum on challenges faced by competition authorities in a digital world, (2019).

82 Autorité de la concurrence: L’Autorité publie sa contribution au débat sur la politique de concurrence face aux enjeux posés par l'économie numérique (2020. február 21.).

83 Bundeskartellamt: Amendment of the German Act against Restraints of Competition (2021. január 19.).

84 CMA: Online platforms and digital advertising. Market study final report (2020. július 1.).

85 Bundeskartellamt: Joint paper of the heads of the national competition authorities of the European Union. How national competition agencies can strengthen the DMA (2021. június 22.) 28. pont.

Stigler Committee on Digital Platforms Final Report. Chicago Booth, 2019. szeptember 16.

87 W. Kip Viscusi - Joseph E. Harrington - John M. Vernon: Economics of Regulation and Antitrust. $4^{\text {th }}$ Edition, MIT Press Books, 2005. 569. 
A DMA-javaslat 12. cikke előírja, hogy a kapuőrvállalkozásoknak értesíteniük kell a Bizottságot minden általuk tervezett, más alapvető platformszolgáltatást nyújtó vagy digitális szektorban érdekelt vállalkozást érintő összefonódásról abban az esetben is, ha az összefonódás nem érné el a vállalkozások közötti összefonódásról szóló 139/2004/EK tanácsi rendelet ${ }^{90}$ szerinti joghatósági küszöböt. Kérdéses azonban, hogy mit kezd a Bizottság ezzel a lehetőséggel, amikor a múltban több olyan engedélyköteles fúziós ügy is volt, amelyek jóváhagyása után komoly versenyaggályokat fogalmaztak meg. Ilyen a Google/DoubleClick, ${ }^{91}$ amelynek a következményeként a Google olyan vertikálisan integrált online hirdetési vállalkozássá vált (hiszen a DoubleClick megszerzése tette számára lehetővé a böngészési adatok megismerését), amely mára az online hirdetési piac főbb problémáinak egyike lett. A másik ilyen a Facebook-Whatsapp összefonódás engedélyezése. ${ }^{92} \mathrm{~A}$ francia versenyhatóság ágazati vizsgálata szerint is a Facebook és a Google mára az online hirdetési piac meghatározó szereplői, mert nagyszámú felhasználó böngészési adatai alapján képesek célzott hirdetések kínálására. ${ }^{93} \mathrm{Az}$ EU Bizottság szakértői tanulmánya ${ }^{94}$ ezért azt ajánlotta, hogy a kapuőrplatformok olyan felvásárlásainál, amikor a céltársaság kisebb, kiegészítő jellegű szolgáltatást nyújt, fogadjon el egyfajta ökoszisztéma alapú megközelítést. Ez a szakértői jelentés szerint annak vizsgálatát jelentené, hogy a kiegészítő jellegű szolgáltatás megszerzése mennyiben teszi lehetővé a domináns szereplő számára a piaci hatalma kiterjesztését és ezáltal az egész ökoszisztéma további erősítését. Van olyan vélemény, hogy az EU Bizottság 2020. decemberi Google Fitbit feletti irányításszerzést jóváhagyó döntése ${ }^{95}$ elmulasztotta az összefonódás e szakértői jelentés szempontjából való vizsgálatát. ${ }^{96}$ Másfelől viszont el kell ismerni, hogy egyfajta strukturális kötelezettségként az EU Bizottság előírta a Fitbit adatainak silóban tartását, nevezetesen, hogy azokat nem lehet a Google hirdetési szolgáltatásaihoz felhasználni, mert az online keresés alapú hirdetési piacokon a Fitbit adataival a Google már amúgy is fennálló domináns pozíciója tovább erősödött volna.

\subsection{Az EU adatstratégiája}

Az EU adatstratégiája kifejezetten is elismeri, hogy „jelenleg a világ adatainak nagy részét néhány technológiai nagyvállalat birtokolja. Ez visszafoghatja az adatvezérelt

\footnotetext{
90 A Tanács 139/2004/EK rendelete (2004. január 20.) a vállalkozások közötti összefonódások ellenőrzéséről (az EK összefonódás-ellenőrzési rendelete) EGT vonatkozású szöveg.

91 COMP/M.4731 - Google/DoubleClick, 340. 363. COMP/M.7217 - Facebook/Whatsapp.

93 Autorité de la concurrence: L’Autorité rend son avis sur la publicité en ligne (2018. március 6.). Ezt csak súlyosbítják az egyéb versenykorlátozások, mint amit a Bizottság is megállapított 2019-es döntésében [COMP/AT.40411 — Google Search (AdSense)], hogy a Google versenytárs keresési hirdetések elhelyezését nem biztosítja a hirdetési felületeket biztosító partnerhálózatában.

94 Jacques Crémer - Yyes-Alexandre de Montjoye - Heike Schweitzer: Competition Policy for the digital era (final report). European Commission, 2019.

95 Case M.9660 - Google/Fitbit 964-973. pontok.

96 Jay Modrall: Google/Fitbit - The EU Commission Misses a Step. Kluwer Competition Law Blog, 2021. június 17.
} 
vállalkozások megjelenését, növekedését és innovációját az EU-ban”. ${ }^{97} \mathrm{Az}$ EU egyik fő stratégiai kérdése a 21. században, hogy miként tudja visszaszerezni a kontrollt adatvagyona felett, csökkenteni az adatok elvesztéséhez vezető technológiai kiszolgáltatottságot. Az EU szerint a jövő adatainak nagy része ipari és szakmai alkalmazásokból, közérdekű szakterületekről vagy a dolgok internetével kapcsolatos alkalmazásokból fog származni, ${ }^{98}$ aminek érdekében egyensúlyt kell teremteni az adatok áramlása és széles körű felhasználása, illetve a magánéletre, a védelemre, a biztonságra és az etikai kérdésekre vonatkozó magas szintû normák megőrzése között. ${ }^{99}$ „A Bizottság jövőképe az európai értékekre, az alapvető jogokra és azon meggyőződésre épül, hogy gondolkodásunk és cselekedeteink középpontjában az embernek kell állnia." ${ }^{100}$ Ez lenne tehát az EU útja a digitális szuverenitás visszaszerzésére, aminek elmulasztása „azzal a kockázattal jár, hogy az uniós polgárok és vállalkozások adataihoz olyan harmadik országbeli joghatóságok férnek hozzá, amelyek nincsenek összhangban az EU adatvédelmi keretével". ${ }^{101}$ Az adatstratégia mind Kínával, mind pedig az USA-val kapcsolatosan megfogalmaz ilyen aggályokat. Az EU adatstratégiája egyfajta harmadik utas megoldásként az adatok szabad áramlása és védelme mellett teszi le a voksát. Ennek érdekében már eddig történtek intézkedések.

Az EU 2018. november 14-i a nem személyes adatok Európai Unióban való szabad áramlásának keretéről ${ }^{102}$ szóló 2018/1807. rendelete előírja a tagállamoknak, hogy 24 hónapon belül felül kell vizsgálniuk a nemzeti adatlokalizációs korlátozásokat, és közérdek hiányában el kell törölni a nem személyes adatok EU-n belüli áramlását akadályozó ilyen előírásokat, amelyek jellemzően abból a félelemből táplálkoznak, hogy majd így nem állnak a nemzeti hatóságok rendelkezésére. ${ }^{103} \mathrm{Ez}$ áthidalható úgy, ha a hozzáférési jogot megkapják a hatóságok függetlenül attól, hol van tárolva az adat. Például az ECN+ irányelv ${ }^{104}$ alapján is a nemzeti versenyhatóságoknak minden olyan adathoz hozzá kell férniük, amelyek az eljárás alá vont vállalkozások számára hozzáférhetők, függetlenül azok fizikai elhelyezkedésétől.

A 2019-es nyílt hozzáférési irányelv továbbá a közszféra információinak és a közpénzből finanszírozott információknak a széles körű, Unió-szerte történő további felhasználása miatt írja elő az akadályok elhárítását például éppen a mesterséges intelligencia fejlesztésének további előmozdítása érdekében. ${ }^{105}$

$97 \quad$ Európai Bizottság: A Bizottság Közleménye az Európai Parlamentnek, a Tanácsnak, az Európai Gazdasági és Szociális Bizottságnak és a Régiók Bizottságának: Európai adatstratégia COM(2020) 66 végleges (2020. február 19.). 3.

$98 \operatorname{COM}(2020) 663$.

$99 \operatorname{COM}(2020) 664$.

$100 \operatorname{COM}(2020) 665$.

$101 \operatorname{COM}(2020) 6610$.

102 Az Európai Parlament és a Tanács (EU) 2018/1807 rendelete (2018. november 14.) a nem személyes adatok Európai Unióban való szabad áramlásának keretéről.

103 Az Európai Parlament és a Tanács (EU) 2018/1807 rendelete.

104 Az Európai Parlament és a Tanács (EU) 2019/1 irányelve (2018. december 11.) a tagállami versenyhatóságok helyzetének a hatékonyabb jogérvényesítés céljából történő megerősítéséről és a belső piac megfelelő mủködésének biztosításáról 6. cikk (1) bekezdés b) pont és 8. cikk.

105 Az Európai Parlament és a Tanács (EU) 2019/1024 irányelve (2019. június 20.) a nyílt hozzáférésű adatokról és a közszféra információinak további felhasználásáról. 
Az EU adatstratégiája ilyen előzmények után összesen három területen irányoz elő intézkedéseket:

1. az adatkormányzás megfelelő szabályozási hátterének megteremtése;

2. a közös európai adatterek kiépítésének elősegítése a közérdekű stratégiai ágazatokban, az adatok szélesebb körű hozzáférhetővé tétele érdekében, hogy nagy értékű nyilvános adatkészletek nyíljanak meg az egész EU-ban, lehetővé téve az ingyenes újrafelhasználást;

3. a magánszféra adatai megosztásának előmozdítása (B2B adatcsere), továbbá a biztonságos, tisztességes és versenyképes felhőszolgáltatásokhoz való hozzáférés biztosítása.

2020. november 25-én az Európai Bizottság közzétette a közös európai adatterek irányítását lehetővé tevő jogi keret létrehozására, a Data Governance rendeletre (DGR) vonatkozó javaslatát, ${ }^{106}$ amely három célt tűzött ki. Egyrészt egy olyan mechanizmus létrehozását, amely elősegíti a védett közszféra adatai bizonyos kategóriáinak megosztását és újrafelhasználását, amelyekre a személyes adatok védelme, szellemi tulajdonjog vagy üzleti titoktartás vonatkozik, így ezért nem tartozik a 2019. évi nyílt adatokról szóló irányelv hatálya alá. Másrészt új jogi rendszer létrehozását, az úgynevezett adatmegosztó szolgáltatók számára, akiknek semlegesnek kell maradniuk a kicserélt adatok tekintetében. Harmadrészt pedig, az úgynevezett adataltruizmus elősegítését, vagyis annak ösztönzését, hogy az egyének vagy vállalatok önként járuljanak hozzá adataik közjó célú felhasználásához. A DGR tehát alternatív modellt kínál a nagy technológiai platformok adatkezelési gyakorlatával szemben, amelyek piaci előnyre tettek szert az üzleti modelljeiknek köszönhetően felhalmozott nagy mennyiségű adatra visszavezethetően. ${ }^{107} \mathrm{Ez}$ az új megközelítés a bizalom növelése érdekében egy olyan modellt javasol, amely az adatközvetítók semlegességén és átláthatóságán alapulna. Ennek a semlegességnek a biztosítása érdekében az adatmegosztó közvetítő nem kereskedhet az adatokkal saját javára, és szigorú követelményeknek kell megfelelnie.

Az Európai Bizottság adatstratégiájában jelezte, hogy a piaci szereplők közti (B2B) adatmegosztást egy 2021-re tervezett adattörvényben főszabályként önkéntesen ösztönözné, de bizonyos szektorok esetében akár kötelezővé is tenné FRAND (fair, reasonable, and non-discriminatory) alapon, ha a versenyjog nem lenne elégséges. ${ }^{108}$ Létezik már ilyen szektorális szabályozási előírás kötelező adatmegosztásra például az autójavítás körében használatos egyes információk megosztásáról ${ }^{109}$ vagy a pénzügyi szektorban. ${ }^{110}$ Azért lényeges az óvatosság és a differenciált megközelítés egyes szektorok és az adatok

106 European Commission: Proposal for a Regulation of the European Parliament and of The Council on European data governance (Data Governance Act) COM(2020) 767 final (2020. november 25.).

107 European Commission: Commission proposes measures to boost data sharing and support European data spaces (2020. november 25.).

$108 \operatorname{COM}(2020) 6616$.

109 Az Európai Parlament és a Tanács 715/2007/EK rendelete (2007. június 20. ) a könnyű személygépjármúvek és haszongépjármúvek (Euro 5 és Euro 6) kibocsátás tekintetében történő típusjóváhagyásáról és a jármújavítási és -karbantartási információk elérhetőségéről.

110 Az Európai Parlament és a Tanács (EU) 2015/2366 irányelve (2015. november 25.) a belső piaci pénzforgalmi szolgáltatásokról és a 2002/65/EK, a 2009/110/EK és a 2013/36/EU irányelv és a 1093/2010/ EU rendelet módosításáról, valamint a 2007/64/EK irányelv hatályon kívül helyezéséről. 
jelentősége mentén a kötelező adatmegosztással kapcsolatosan, mert az hátrányosan hathat az innovációra. ${ }^{111}$

A technológiai nagyvállalatok hatalmas mértékủ adatfelhalmozásának, felhasználásának és adataik megosztásának kérdésével nem az Adattörvény, hanem a Bizottság DMA javaslata foglalkozik. A Bizottság DMA javaslata a kapuőrplatformok üzleti és végfelhasználókkal szembeni tisztességtelen gyakorlatait szorítaná további keretek közé. A DMA-javaslat 6. cikk i) pont kimondaná, hogy a kapuőrök nem akadályozhatják a harmadik fél eladókat abban, hogy hozzáférjenek a kapuőrök által az üzleti felhasználók vásárlóinál összegyüjtött alapvető információkhoz, feltéve, hogy ezen ügyfelek beleegyeznek az információk megosztására harmadik felekkel. A DMA-javaslat 5. cikk a) pontja szerint a kapuőr tartózkodik az alapvető platformszolgáltatások használatából származó személyes adatoknak a kapuőr által kínált egyéb szolgáltatások során való felhasználásától. A DMA-javaslat 6. cikk a) pontja szerint a kapuőr tartózkodik attól, hogy az üzleti felhasználókkal való verseny során felhasználja azokat a nyilvánosan nem elérhető adatokat, amelyek az alapvető platformszolgáltatása üzleti felhasználóinak tevékenységein keresztül keletkeznek. A javaslat 6. cikk j) pontja előírná az anonimizált keresőmotor click\&query adatokhoz való hozzáférésének biztosítását a versenytárs keresőmotor-szolgáltatást nyújtók számára, hogy fejleszthessék algoritmusaik minőségét. Ilyen javaslattal a brit versenyhatóság is előállt, hiszen ezen adatok tekintetében méretelőnyről beszélhetünk, mivel minél több ilyen adat van a keresőmotoroknál, annál jobban képesek fejleszteni algoritmusaikat. ${ }^{112}$

Fentiek alapján megállapítható, hogy a nagy technológiai óriások adatelszívó gyakorlatát egyetlen EU-s kezdeményezés sem érintené vagy próbálná keretek közé szorítani. Emiatt viszont nem látszik, hogy az EU kitettsége ezen a téren csökkenne. A fenti kezdeményezések egyrészt az európai adatvagyon alternatív (technológiai óriások adatvagyona melletti) módszerekkel való megteremtését célozzák, másrészről a technológiai óriások adatvagyonával való gazdálkodást érintenék a DMA-javaslat által. A DMA így tilalmazná a kapuőrök különböző szolgáltatásaiból származó felhasználói adatainak kombinálását, hogy az üzletfelek adatait a kapuőrplatform saját célra használja fel, és biztosítani kellene, hogy az üzletfelek saját felhasználóik adatait a GDPR-t betartva megismerhessék. A DMA-javaslat sem tartalmaz azonban átfogó, technológiai óriások által birtokolt adatvagyonhoz versenytársi hozzáférést biztosító kötelezettséget az anonimizált keresőmotor click\&query adatokhoz való hozzáférésen kívül. Az EU 2021-re előirányzott adattörvénye viszont előmozdítaná az adatcsere-megállapodásokat, és ezáltal a technológiai óriások által birtokolt adatvagyon legalább tágabb körben megnyílhatna és felhasználható lenne, viszont továbbra sem akadályozná az adatok zéróáras üzleti modellel való USA-ba szívását. Meg kell jegyezni, hogy az adatok Európában tartását (például adatlokalizációs előírások révén) korlátozza a GATS, amely tiltja a külföldi szolgáltató helyi szolgáltatóhoz képesti hátrányos megkülönböztetését, a helyi szolgáltató kedvezőbb elbírálását. ${ }^{113}$ Ezért olyan megoldást kell találni, amely összhangban van

Government of the Netherlands: Dutch Vision on Data Sharing between Businesses (2019. február 1.). CMA (2020): i. m. 90. pont.

Holger Hestermeyer - Laura Nielsen: The Legality of Local Content Measures under WTO Law. Journal of World Trade, 48. (2014), 3. 553. 
a nemzetközi kereskedelmi megállapodásokkal. Ehhez magát az ingyenesség látszatára építő (zéróáras) üzleti modell adatelszívó hatását kellene tompítani. A brit versenyhatóság tanulmánya ${ }^{114}$ is az üzleti modell kérdését feszegeti, amikor felveti, hogy az online platformoknak biztosítaniuk kellene a felhasználóknak annak választását, hogy kívánnak-e személyre szabott reklámokat kapni vagy sem, és ekkor csak általános reklámozással szembesülnének. Ezt a gondolatot kellene továbbvinni a személyes adatok feletti önrendelkezés jogának hatékonyabb biztosítása érdekében. Az adattal fizetés üzleti modelljét ismeri el a szabályozás szintjén az EU 2019/770 irányelve a digitális tartalom szolgáltatására és digitális szolgáltatások nyújtására irányuló szerződések egyes vonatkozásairól. ${ }^{115} \mathrm{Ez}$ az irányelv biztosítékokat kínál azon szerződésekre, amelyek keretében a kereskedő a fogyasztónak digitális tartalmat szolgáltat vagy digitális szolgáltatást nyújt, illetve erre kötelezettséget vállal, a fogyasztó pedig személyes adatokat ad át, illetve erre kötelezettséget vállal. ${ }^{116} \mathrm{Az}$ adattal fizetés üzleti modelljét az EU Adatvédelmi Biztosa ellentétesnek tartotta az adatvédelem szellemiségével, mert a személyes adatok védelme alapvető jog, és ezért a személyes adatok nem tekinthetők árunak. ${ }^{117}$ Álláspontom szerint azonban az adattal fizetés nem jelenti az adatvédelem erózióját, sőt éppen azt erősítené. Ehhez arra lenne szükség, hogy a technológiai óriások kötelezően biztosítsák a választás lehetőségét a felhasználóknak: adataikkal vagy pénzzel fizetnek a szolgáltatásaikért. Bár az EU 2019/770 irányelv azokra a helyzetekre nem alkalmazandó, amikor a fogyasztó anélkül, hogy szerződést kötött volna a kereskedővel, csak azért kénytelen reklámokat megtekinteni, hogy hozzáférhessen egy digitális tartalomhoz vagy egy digitális szolgáltatáshoz, a tagállamok azonban továbbra is szabadon dönthetnek úgy, hogy kiterjesztik ezen irányelv alkalmazását az irányelv hatálya alá nem tartozó ilyen helyzetekre, illetve egyébként szabályozzák e helyzeteket. ${ }^{118} \mathrm{Az}$ irányelv 8. cikk (1) bekezdés b) pontja értelmében a digitális szolgáltatásnak meg kell felelni a nyilvánosan tett kereskedői kijelentésekből fakadó fogyasztói elvárásoknak. Így tehát egy ingyenes kijelentés azt eredményezi, hogy azért cserébe személyes adat sem szedhető be. ${ }^{119}$

\subsection{Az EU gazdasági nyitottságának csökkentése}

Az EU a világ egyik legnyitottabb gazdasága, és a közvetlen külföldi befektetések fő célpontja a világon: a harmadik országbeli befektetők EU-beli közvetlen befektetési állománya 2017 végén 6441 milliárd eurót tett ki, és 16 millió munkahelyet biztosított

\footnotetext{
$114 \quad$ CMA (2020): i. m. 386-387.

115 Az Európai Parlament és a Tanács (EU) 2019/770 irányelve (2019. május 20.) a digitális tartalom szolgáltatására és digitális szolgáltatások nyújtására irányuló szerződések egyes vonatkozásairól (EGT-vonatkozású szöveg.).

116 EU 2019/770 irányelv, 24. preambulum-bekezdés.

117 Opinion 4/2017 of the European Data Protection Supervisor on the Proposal for a Directive on certain aspects concerning contracts for the supply of digital content.

118 EU 2019/770 irányelv, 25. preambulum-bekezdés.

119 Lásd ebben a tekintetben a Gazdasági Versenyhivatal Facebookkal szembeni elmarasztaló döntését az ingyenesség megtévesztő állítása miatt: Gazdasági Versenyhivatal: 1,2 milliárd Ft bírságot szabott ki a Gazdasági Versenyhivatal a Facebook-ra (2019. december 6.).
} 
az európaiak számára. ${ }^{120} \mathrm{Az}$ EU külföldi befektetésekkel kapcsolatos stratégiai érdekeinek védelme céljából elfogadott 2019/452 EU rendelet ${ }^{121}$ olyan együttmúködési mechanizmust hozott létre, amelynek keretében a tagállamok és a Bizottság információkat cserélhetnek, illetve szükség esetén aggályokat vethetnek fel az egyes befektetésekkel kapcsolatban. Ez a rendelet lehetővé teszi a Bizottság számára, hogy véleményt fogalmazzon meg, ha egy befektetés egynél több tagállam biztonságát vagy közrendjét fenyegeti, vagy ha a befektetés hátrányosan érinthet valamely, az Unió egészének érdekét szolgáló projektet. A rendelet alapvető követelményeket állapít meg azon tagállamok számára, amelyek biztonsági vagy közrendi okokból nemzeti szintű átvilágítási mechanizmust működtetnek vagy vezetnek be, továbbá ösztönzi a befektetések átvilágításával kapcsolatos legjobb gyakorlatok és tapasztalatok megosztását. Van olyan vélemény, hogy ezeket a nemzeti befektetésátvilágítási mechanizmusokat EU-szintre kellene emelni a protekcionizmus elkerülése érdekében. ${ }^{122}$

Az EU joga jelenleg még nem tartalmaz előírásokat azokra a külföldi támogatásokra, amelyek tisztességtelen előnyhöz juttatják kedvezményezettjeiket az EU-ban müködő vállalkozások felvásárlása, az EU-n belüli közbeszerzési eljárásokban való részvétel során. ${ }^{123}$ Ezért az EU Bizottság 2021 májusában rendeletjavaslatot nyújtott be, amelynek értelmében a Bizottság rendelkezne majd hatáskörrel a nem uniós országok által az EU-ban gazdasági tevékenységet folytató vállalkozásoknak nyújtott pénzügyi hozzájárulások vizsgálatára, és adott esetben korrekciós intézkedések alkalmazására. A javaslat három eszköz bevezetését veti fel, amelyek közül kettő bejelentésen alapul, egy pedig általános piacvizsgálati eszköz lenne. Az egyik bejelentésen alapuló eszköz olyan összefonódások vizsgálatára szolgál, amelyek nem uniós kormányzattól származó pénzügyi hozzájárulást tartalmaznak, és a céltársaság 500 millió eurót meghaladó árbevétellel rendelkezik az EU-n belül, a külföldi pénzügyi hozzájárulások mértéke pedig meghaladja az 50 millió eurót. A másik bejelentésen alapuló eszköz olyan közbeszerzési ajánlatok vizsgálatára szolgál, amelyek nem uniós kormányzattól származó pénzügyi hozzájárulást tartalmaznak, és a közbeszerzési pályázat becsült értéke legalább 250 millió euró. A harmadik eszköz minden egyéb piaci helyzet, valamint kisebb összefonódások és közbeszerzési eljárások vizsgálatára szolgál, amelyek esetében a Bizottság hivatalból vizsgálatot indíthat. A bejelentett ügyletek esetében a Bizottság hatáskörrel rendelkezne arra, hogy megtiltsa a támogatott felvásárlást, vagy azt, hogy a közbeszerzési szerződést a támogatott ajánlattevőnek ítéljék oda. Bár az EU Bizottság javaslata egyaránt vonatkozik minden külföldről támogatott nem európai szervezetre, egyes vélemények szerint a javaslat mögött egyértelműen Kína európai technológiai cégben való részesedésszerzése elleni védekezés motivációja húzódik meg. ${ }^{124}$ Kína igyekszik

120 Európai Bizottság: Megkezdi müködését a közvetlen külföldi befektetésekre vonatkozó uniós átvilágítási mechanizmus (2020. október 9.).

121 Regulation (EU) 2019/452 of the European Parliament and of the Council of 19 March 2019 establishing a framework for the screening of foreign direct investments into the Union.

122 Vig Zoltán: The Regulation of Screening of Foreign Direct Investments in the European Union. Pro Futuro, 10. (2021), 4. 9-24.

123 Európai Bizottság: A Bizottság új rendeletet terjesztett elő a külföldi támogatások egységes piacon belüli torzító hatásainak kezelése érdekében (2021. május 5.).

124 Laurie Clarke: The EU's crackdown on state-subsidised companies is aimed squarely at China. Techmonitor, 2021. május 6. 
ugyanis saját internetes ökoszisztémáját kiépíteni, és ennek jegyében az utóbbi időkben különösen német technológiai vállalatok felvásárlásában volt aktív. ${ }^{125}$

\subsection{A jogellenes és káros tartalmak elleni küzdelem}

A kommunikáció még sohasem volt ennyire olcsó, gyors és anonim, ${ }^{126}$ ami természetesen teret ad nem csak a vállalható, de a káros, erősen kérdéses, vállalhatatlan és akár jogellenes tartalmaknak is. Az online platformok saját jól felfogott üzleti érdekeik miatt moderálják a tartalmakat, mert így akarják elkerülni, hogy nagy ügyfelek távol tartsák magukat vagy minimalizálják a platform használatát. Például a Facebook 2019-ben felállított egy felügyeleti tanácsot a tartalom moderálásával kapcsolatos döntések fellebbezéseinek elbírálására, amely elvileg a cég vezetőitől független hatáskörrel rendelkezik a tartalmi döntések felülvizsgálatára. A platformok moderálási gyakorlata ugyanakkor nem egyszer politikai kontextusba került, ${ }^{127}$ amely miatt a moderálás átlátható, transzparens, jogorvoslatot biztosító gyakorlata különösen is fontos.

A tartalom szűrése - legyen az állami vagy magánpiaci - mindenképpen érzékeny kérdés. Egyfelől ugyanis ez érinti a véleménynyilvánítás szabadságát, másfelől viszont a jogellenes vagy káros tartalmak jelentős társadalmi, politikai kockázatokat hordoznak és komoly károkat okozhatnak. Egy felmérés alapján a megkérdezettek 82\%-a szerint az álhírek és a dezinformáció veszélyt jelentenek a demokráciára. ${ }^{128}$ Jelentősen nő az online szolgáltatásokkal való visszaélés is: például a hamisított termékek behozatala Európában 2016-ban 121 milliárd eurót tett ki. ${ }^{129}$ Növekvő problémát okoz a szellemi tulajdonjogokat sértő tartalom, a gyermekek szexuális bántalmazása (amely 2017 és 2019 között megduplázódott), a terroristatartalom, az illegális gyúlöletbeszéd és az egyéneket megcélzó illegális hirdetések terjesztése is. A káros online tartalmak - például a közösségi médiában történő zaklatás, a dezinformációs tartalom és az álhírek - is egyre több kérdést vetnek fel (például hamis információk terjedése a Covid-19-járványról vagy az oltásról).

A Bizottság hangsúlyozza, hogy fontos egyensúlyt kell elérni az illegális tartalom eltávolítása érdekében hozott intézkedések és az alapvető jogok, különösen a véleménynyilvánítás szabadsága és a vállalkozás szabadsága között. ${ }^{130}$ E tekintetben a hivatkozott Bizottsági hatásvizsgálat megállapította, hogy a platformok jelenleg nem védik megfelelően a felhasználóik alapvető jogait. A platformok széles körű mérlegelési jogkörrel

125 Amy Borrett: Is Chinese investment in Europe’s technology industry a threat? Techmonitor, 2021. április 14.

126 Kyle Langvardt: Regulating Online Content Moderation. Georgetown Law Journal, 106. (2017), 5. 1359.

1272020 Facebook ad boycotts. Wikipedia, (é. n.).

128 Carla Hobbs (szerk.): Europe's digital sovereignty: From rulemaker to superpower in the age of US-China rivalry. 2020. július 30 .

129 Tambiama Madiega: Digital services act. European Parliamentary Research Service, PE 689.357 - March 2021. 4.

130 European Commission: Commission Staff Working Document, Impact Assessment Report Accompanying the document Proposal for a Digital Markets Act $\{C O M(2020) 842$ final $\}-\{$ SEC(2020) 437 final $\}-\{S W D(2020)$ 364 final\} (2020. december 15.).

Európai Tükör 2021/2. 
rendelkeznek szolgáltatási feltételeik alapján, és döntéseik gyakran nem a tartalom jogszerűségének értékelésén alapulnak. Ennek eredményeként a téves eltávolítások károsan hathatnak a felhasználók véleménynyilvánításának szabadságára, valamint az online piacterektől függő kereskedőkre.

Ezekre figyelemmel tett javaslatot az EU Bizottság 2020 decemberében a Digital Services Act-re ${ }^{131}$ (DSA). A DSA-tervezet a DSA hatálya alá tartozó összes közvetítő szolgáltatóra nézve előírná a szolgáltatásaik használatára vonatkozó összes korlátozás közzétételének kötelezettségét. Ezenkívül kötelesek lennének felelősségteljesen fellépni a korlátozások alkalmazásában és érvényesítésében, ideértve a tartalom moderálásához használt eszközök, például az algoritmikus döntéshozatali felülvizsgálat használatát is (12. cikk). Valamennyi szolgáltatónak jelentést kell tennie az illegális tartalomnak tekintett vagy a szolgáltató feltételeivel ellentétes információk eltávolításáról és letiltásáról is (13. cikk). Mind az online platformoknak, mind a tárhelyszolgáltatóknak értesítési és cselekvési mechanizmusokat kellene bevezetniük, amelyek lehetővé teszik harmadik felek számára, hogy jelentsék az állítólagos illegális tartalmat (14. cikk), továbbá indokolást kell adjanak, amikor úgy határoznak, hogy eltávolítják vagy letiltják a konkrét információkhoz való hozzáférést (15. cikk). Könnyen hozzáférhető és felhasználóbarát belső panaszkezelési eljárást kell létrehozniuk felhasználóik számára (17. cikk). A javaslat bevezeti a megbízható jelzők fogalmát is, azokra a tagállami hatóságok által kinevezett szervekre, amelyek az illegális tartalom elleni küzdelem terén különös szakértelemmel rendelkeznek. Az online platformok kötelesek lennének elsődlegesen feldolgozni a megbízható jelzőktől érkező értesítéseket (19. cikk), és tájékoztatniuk kellene az illetékes végrehajtó hatóságokat abban az esetben, ha tudomást szereznének bármely olyan információról, amely súlyos bűncselekmények gyanúját veti fel, veszélyt jelent az emberek életére vagy biztonságára (21. cikk). Ezenkívül a javaslat bevezeti az „ismerje meg az üzleti ügyfeleket” elvet, amely alapján a platformok kötelesek lesznek a kereskedőktől beszerezni és ellenőrizni az azonosító adatokat, mielőtt lehetővé tennék számukra a szolgáltatásaik használatát (22. cikk). A 45 millió havi felhasználóval rendelkező óriási platformoknak évente legalább egyszer értékelniük kell a szolgáltatásaik müködéséből és használatából eredő rendszerszintű kockázatokat (26. cikk). A kockázat három kategóriáját különbözteti meg a DSA:

1. felhasználói által elkövetett esetleges visszaélések (például illegális tartalom, gyermekekkel való szexuális visszaélést okozó anyagok terjesztése, hamisított termékek forgalmazása);

2. szolgáltatásaiknak az alapvető jogokra (például a magánéletre, a véleménynyilvánítás szabadságára) gyakorolt hatása, például algoritmikus rendszereik kialakítása miatt, és

3. szolgáltatásaik szándékos manipulálása, például hamis felhasználói profilok létrehozása által.

131 European Commission: Proposal for a Regulation of the European Parliament and of the Council on a Single Market For Digital Services (Digital Services Act) and amending Directive 2000/31/EC COM(2020) 825 final (2020. december 15.). 
Az óriási platformoknak a kockázatértékelés fényében meg kell tenniük a megfelelő enyhítő intézkedéseket (27. cikk), például a tartalommoderálás, algoritmikus ajánlórendszereik és online interfészeik múködésének kiigazítására annak érdekében, hogy azok visszatartsák és korlátozzák az illegális tartalom terjesztését. Külső és független ellenőrzéseknek is alá kell vetni magukat (28. cikk): elérhetővé kell tenni a Bizottság és független kutatók számára a megfelelés ellenőrzéséhez szükséges adatokat, valamint megfelelési tisztségviselőt kell kinevezniük. Ebben az értelemben a DSA elmozdulást jelent a jelenlegi önszabályozás felől a társszabályozási és szabályozási mechanizmusok felé. ${ }^{132}$

\section{4. Összegzés}

Az EU célja a digitális korban is az, hogy megőrizze értékeit, ezért a digitális kor kihívásainak megválaszolásakor is ennek megfelelően kívánja járni a saját útját. Ennek egyik legmarkánsabb megjelenése a szabályozás, amelynek az EU a fő innovátora a világban. Olyannyira, hogy a digitális kor szabályozásában az akadémiai szférát is megelőzi, amelynek sok esetben csak az EU-s szabályozási javaslatok utólagos értékelése és nem de lege ferenda alakítása marad.

$\mathrm{Az}$ EU a digitális szuverenitás elérése egyik fő eszközének (a technológiai befektetések ösztönzése és támogatása mellett) az értékei mentén múködő szabályozást választotta. Az EU Bizottság 2019-2024 közötti stratégiájának prioritásai között szerepel az EU digitális korra való felkészítése, aminek fókuszában az embereket szolgáló technológiák, a tisztességes verseny és a nyílt internet áll. Ennek biztosítása érdekében a Bizottság több szabályozási intézkedést is hozott, illetve előirányzott, amelyek hozzájárulhatnak az EU digitális szuverenitásának a növeléséhez: kiberbiztonság, adóztatás, technológiai óriások piaci dominanciája elleni küzdelem, adatok védelme és elérhetővé tétele, gazdasági nyitottság csökkentése, mesterséges intelligencia fejlesztése, az internet nyitottságának biztosítása. Az egységes digitális adón kívül az EU mindegyik területen elért eddig valamilyen eredményt. A mesterséges intelligenciát illetően a világ első szabályozási javaslatát alkotta meg. A kiberbiztonság terén pedig elindult az EU-s szabványosítás. A technológiai óriások dominanciájának kordában tartására az EU a versenyhatóságok kezdeményezésére versenyjogot meghaladó szabályozást tervez, amellyel kapcsolatos hatáskörök élvezői - úgy tűnik - maguk a versenyhatóságok lesznek, amelyeket azonban bírálatok értek amiatt, hogy a technológiai óriások növekedését sokáig tétlenül nézték. Mindenképpen figyelemre méltó fejlemény, hogy az EU-ban a versenyhatóságok ilyen értelemben megerősödve kerülnek ki a kritikákból. A jogellenes és káros internetes tartalmakkal szemben az EU a DSA-javaslattal elmozdulna a jelenlegi önszabályozás felől a társszabályozási és szabályozási mechanizmusok felé.

Az EU egyik fő stratégiai kérdése a 21. században, hogy miként tudja visszaszerezni a kontrollt adatvagyona felett, csökkenteni az adatok elvesztéséhez vezető technológiai kiszolgáltatottságot. Ennek kapcsán megállapítható, hogy az ebben a körben született eddigi EU-s kezdeményezések a zéróáras üzleti modellel megvalósuló adatelszívást

$132 \quad$ Madiega (2021): i. m. 7. 
nem szorítanák keretek közé, emiatt viszont nem látszik, hogy az EU kitettsége ezen a téren csökkenne. Ehhez arra lenne szükség, hogy a technológiai óriások kötelezően biztosítsák a választás lehetőségét a felhasználóknak: adataikkal vagy pénzzel fizetnek a szolgáltatásaikért.

\section{Felhasznált irodalom}

2020 Facebook ad boycotts. Wikipedia, (é. n.). Online: https://en.wikipedia.org/wiki/ 2020_Facebook_ad_boycotts

Állami Számvevőszék: Elemzés a digitális gazdaság megadóztatásának aktuális kérdéseirōl, a modern gazdasághoz illeszkedő új uniós adószabályokról értékelö elemzés figyelemmel a terület ellenörizhetőségére (2020. március 5.).

Apple investigated in UK over ,unfair' App Store claims. BBC, 2021. március 4. Online: www.bbc.com/news/technology-56279514

Autorité de la concurrence: L’Autorité rend son avis sur la publicité en ligne (2018. március 6.). Onine: www.autoritedelaconcurrence.fr/fr/communiques-de-presse/lautor ite-rend-son-avis-sur-la-publicite-en-ligne

Autorité de la concurrence: L'Autorité publie sa contribution au débat sur la politique de concurrence face aux enjeux posés par l'économie numérique (2020. február 21.). Online: www.autoritedelaconcurrence.fr/fr/communiques-de-presse/lautorite-publie-sacontribution-au-debat-sur-la-politique-de-concurrence

Autorité de la concurrence: The Autorité de la concurrence hands out a $€ 220$ millions fine to Google for favouring its own services in the online advertising sector. 2021. június 7. Online: www.autoritedelaconcurrence.fr/en/article/autorite-de-la-concurrence-ha nds-out-eu220-millions-fine-google-favouring-its-own-services

Beyoud, Lydia - Aoife White: Facebook's Libra Currency Gets European Union Antitrust Scrutiny. Bloomberg, 2019. augusztus 20. Online: www.bloomberg.com/news/ articles/2019-08-20/facebook-s-libra-currency-gets-european-union-antitrustscrutiny

Borrett, Amy: Is Chinese investment in Europe's technology industry a threat? Techmonitor, 2021. április 14. Online: https://techmonitor.ai/policy/geopolitics/is-chineseinvestment-europe-technology-industry-threat

Bryant, Jennifer: 3 years in, GDPR highlights privacy in global landscape. IAPP, 2021. május 25. Online: https://iapp.org/news/a/three-years-in-gdpr-highlightsprivacy-in-global-landscape/

Bundeskartellamt: Amendment of the German Act against Restraints of Competition (2021. január 19.). Online: www.bundeskartellamt.de/SharedDocs/Meldung/EN/ Pressemitteilungen/2021/19_01_2021_GWB\%20Novelle.html

Bundeskartellamt: Bundeskartellamt examines linkage between Oculus and the Facebook network (2020. december 10.). Online: www.bundeskartellamt.de/SharedDocs/ Meldung/EN/Pressemitteilungen/2020/10_12_2020_Facebook_Oculus.html 
Bundeskartellamt: Joint paper of the heads of the national competition authorities of the European Union. How national competition agencies can strengthen the DMA (2021. junius 22.). Online: www.bundeskartellamt.de/SharedDocs/Publikation/EN/Others/DMA _ECN_Paper.html;jsessionid=AF567C0C3AB5A4288224A6C113B1A410.1_cid38 1? $\mathrm{nn}=3591568$

Bunn, Daniel: The U.S. Trade Representative Expands Its Digital Services Tax Investigations. Tax Foundation, 2020. június 2. Online: https://taxfoundation.org/us-trade -representative-ustr-digital-services-tax-investigations/

Candelon, François - Martin Reeves: The New Digital World: Hegemony or Harmony? BCG, 2017. november 14. Online: www.bcg.com/publications/2017/strategy-globalization-new-digital-world-hegemony-harmony

Chee, Foo Yun: EU regulators to probe Alexa, Siri and other voice assistants. Reuters, 2020. július 16. Online: www.reuters.com/article/us-eu-antitrust-tech-idUSKCN24H1VP

Clarke, Laurie: The EU's crackdown on state-subsidised companies is aimed squarely at China. Techmonitor, 2021. május 6. Online: https://techmonitor.ai/policy/eu-foreign-subsidies-legislation-china

CMA opens investigation into possible abuse of dominance arising from Google's „Privacy Sandbox” browser changes. Practical Law, 2021. január 8. Online: https:// uk.practicallaw.thomsonreuters.com/w-029-1182?transitionType=Default\&contextData $=($ sc.Default $) \&$ firstPage $=$ true

Crémer, Jacques - Yves-Alexandre de Montjoye - Heike Schweitzer: Competition Policy for the digital era (final report). European Commission, 2019. Online: https://ec.europa. eu/competition/publications/reports/kd0419345enn.pdf

EDPS: Opinion 8/2016. EDPS Opinion on coherent enforcement of fundamental right since the age of big data (2016. szeptember 23.). Online: https://edps.europa.eu/ sites/edp/files/publication/16-09-23_bigdata_opinion_en.pdf

Egresi Katalin - Pongrácz Alex - Szigeti Péter - Takács Péter: Államelmélet. Győr, Széchenyi István Egyetem, 2016. Online: https://jet.sze.hu/images/Tansz\%C3\%A9ki\%20 Kiadv\%C3\%A1nyok\%202017-18/allamelmelet_tk_2017_06_05-1.pdf

Espinoza, Javier: Brussels asks news groups to describe their data deals with Google. Financial Times, 2019. december 9. Online: www.ft.com/content/a6183776-1a7411ea-97df-cc63de1d73f4

Espinoza, Javier - James Politi: US warns EU against anti-American tech policy. Financial Times, 2021. június 15. Online: www.ft.com/content/2036d7e9-daa2-445d-8f88$6 f$ cee745a259

Európai Bizottság: A Bizottság Közleménye az Európai Parlamentnek, a Tanácsnak, az Európai Gazdasági és Szociális Bizottságnak és a Régiók Bizottságának: Európa digitális jövőjének megtervezése COM(2020)67 végleges (2020. február 19.). Online: https:// eur-lex.europa.eu/LexUriServ/LexUriServ.do?uri=COM:2020:0067:FIN:HU:PDF

Európai Bizottság: A Bizottság Közleménye az Európai Parlamentnek, a Tanácsnak, az Európai Gazdasági és Szociális Bizottságnak és a Régiók Bizottságának: Európai adatstratégia $\operatorname{COM}(2020) 66$ végleges (2020. február 19.). Online: https://eur-lex.europa.eu/ legal-content/HU/TXT/?uri=CELEX\%3A52020DC0066

Európai Tükör 2021/2. 
Európai Bizottság: Megkezdi müködését a közvetlen külföldi befektetésekre vonatkozó uniós átvilágitási mechanizmus (2020. október 9.). Online: https://ec.europa.eu/commission/presscorner/detail/hu/ip_20_1867

Európai Bizottság: A Bizottság új rendeletet terjesztett elő a külföldi támogatások egységes piacon belüli torzító hatásainak kezelése érdekében (2021. május 5.). Online: https:// ec.europa.eu/commission/presscorner/detail/hu/ip_21_1982

European Commission: Antitrust: Commission opens investigation into possible anti-competitive conduct of Amazon (2019. július 17.). Online: https://ec.europa.eu/commission/ presscorner/detail/mt/ip_19_4291

European Commission: Antitrust: Commission opens investigation into possible anticompetitive conduct of Facebook (2021. június 4.). Online: https://ec.europa.eu/commission/presscorner/detail/en/ip_21_2848

European Commission: Antitrust: Commission sends Statement of Objections to Amazon for the use of non-public independent seller data and opens second investigation into its e-commerce business practices (2020. november 10.). Online: https://ec.europa.eu/ commission/presscorner/detail/en/IP_20_2077

European Commission: Antitrust: Commission opens investigations into Apple's App Store rules (2020. június 16.). Online: https://ec.europa.eu/commission/presscorner/ detail/en/ip_20_1073

European Commission: Antitrust: Commission opens investigation into possible anticompetitive conduct by Google in the online advertising technology sector (2021. június 22.). Online: https://ec.europa.eu/commission/presscorner/detail/en/ip_21_3143

European Commission: Commission proposes measures to boost data sharing and support European data spaces (2020. november 25.). Online: www.ec.europa.eu/commission/ presscorner/detail/en/ip_20_2102

European Commission: Cloud computing (é. n.). Online: https://digital-strategy.ec.europa. eu/en/policies/cloud-computing

European Commission: Commission Report on safety and liability implications of AI, the Internet of Things and Robotics $\operatorname{COM}(2020) 64$ final (2020. február 19.). Online: https://ec.europa.eu/info/publications/commission-report-safety-and-liability -implications-ai-internet-things-and-robotics-0_en

European Commission: Commission Staff Working Document, Impact Assessment Report Accompanying the document Proposal for a Digital Markets Act $\{\mathrm{COM}(2020)$ 842 final $\}-\{$ SEC(2020) 437 final $\}-\{S W D(2020) 364$ final $\}$ (2020. december 15.)

European Commission: Communication from the Commission to European Parliament, European Council, the Council, the European Economic and Social Committee, the Committee of the Regions, A European strategy for data COM(2020) 66 final (2020 február 19.). Online: https://eur-lex.europa.eu/legal-content/EN/TXT/?uri=CELEX\%3A52020D C0066

European Commission: Communication from the Commission to European Parliament, European Council, the Council, the European Economic and Social Committee, the Committee of the Regions on Artificial Intelligence for Europe COM(2018) 237 final (2018. április 25.). Online: https://eur-lex.europa.eu/legal-content/EN/TXT/?uri $=$ COM\%3A2018\%3A237\%3AFIN 
European Commission: Europe fit for the Digital Age: Commission proposes new rules and actions for excellence and trust in Artificial Intelligence (2021. április 21.). Online: https://ec.europa.eu/commission/presscorner/detail/en/ip_21_1682

European Commission: Inception impact assessment on the Ex ante regulatory instrument Ares(2020) 2877647 (2020. december 16.).

European Commission: Shaping Europe’s digital future (é. n.). Online: https://ec.europa. eu/info/strategy/priorities-2019-2024/europe-fit-digital-age/shaping-europe-digital-future_en

European Commission: Questions and Answers on a Fair and Efficient Tax System in the EU for the Digital Single Market (2018. március 21.). Online: https://ec.europa.eu/ commission/presscorner/detail/en/MEMO_18_2141

European Commission: White Paper on Artificial Intelligence - A European approach to excellence and trust $\operatorname{COM}(2020) 65$ final (2020. február 19.). Online: https:// ec.europa.eu/info/sites/default/files/commission-white-paper-artificial-intelligence-feb2020_en.pdf

European Investment Bank - European Commission: Artificial intelligence, blockchain and the future of Europe. How disruptive technologies create opportunities for a green and digital economy (2021). Online: www.eib.org/attachments/thematic/artificial_intelligence_blockchain_and_the_future_of_europe_report_en.pdf

European Parliament: Security threats connected with the rising Chinese technological presence in the EU and possible action on the EU level to reduce them (2019. március 12.). Online: www.europarl.europa.eu/doceo/document/TA-8-2019-0156_EN.html

Fefer, Rachel F.: EU Digital Policy and International Trade. Congressional Research Service R46732. 2021. március 25. Online: https://crsreports.congress.gov/product/details?prodcode $=\mathrm{R} 46732$

Fleming, Sean: What is digital sovereignty and why is Europe so interested in it? World Economic Forum, 2021. március 15. Online: www.weforum.org/agenda/2021/03/ europe-digital-sovereignty/

Gal, Michal - Nicolas Petit: Radical Restorative Remedies for Digital Markets. Berkeley Technology Law Journal, 37. (2021), 1.

Gazdasági Versenyhivatal: 1,2 milliárd Ft bírságot szabott ki a Gazdasági Versenyhivatal a Facebook-ra (2019. december 6.). Online: www.gvh.hu/sajtoszoba/sajtokozlemenyek/2019_es_sajtokozlemenyek/12-milliard-ft-birsagot-szabott-ki-a-gazdasagi-versenyhivatal-a-facebook-ra

Georgieva, Kristalina - Federico J. Díez - Romain Duval - Daniel Schwarz: Rising Market Power - A Threat to the Recovery? IMF Blog, 2021. március 15. Online: https:// blogs.imf.org/2021/03/15/rising-market-power-a-threat-to-the-recovery/

Government of the Netherlands: Dutch Vision on Data Sharing between Businesses (2019. február 1.) Online: www.government.nl/documents/reports/2019/02/01/ dutch-vision-on-data-sharing-between-businesses

Gönczöl Tünde: A hipszter antitrösztirányzat és kritikusai. In Valentiny Pál - Nagy Csongor István - Berezvai Zombor (szerk.): Verseny és Szabályozás 2018. Budapest, MTA KRTK Közgazdaság-tudományi Intézet, 2019. 13-43. Online: https://kti. krtk.hu/wp-content/uploads/2019/03/Vesz2018_teljes.pdf 
Herszenhorn, David M.- Maia De La Baume: Trump slammed her as a U.S. hating 'tax lady'. She just got a promotion. Politico, 2019 november 27. Online: www.politico. com/news/2019/11/27/margarethe-vestager-eu-tax-promotion-074181

Hestermeyer, Holger - Laura Nielsen: The Legality of Local Content Measures under WTO Law. Journal of World Trade, 48. (2014), 3. 553-591.

Hobbs, Carla (szerk.): Europe's digital sovereignty: From rulemaker to superpower in the age of US-China rivalry. European Council on Foreign Relations, 2020. július 30. Online: https://ecfr.eu/publication/europe_digital_sovereignty_rulemaker_superpower_ age_us_china_rivalry/

Italy fines Google for excluding Enel e-car app from Android Auto. Reuters, 2021. május 13. Online: www.reuters.com/technology/italys-antitrust-fines-google-102-million -euros-abuse-dominant-position-2021-05-13/

Janka, Sebastian Felix - Severin Benedict Uhsler: Antitrust 4.0 - the rise of Artificial Intelligence and emerging challenges to antitrust law. European Competition Law Review, 39. (2018), 3. 112.

Keating, Dave: Why the EU leads in digital regulation, but lags in digital innovation. 2019. október 23. Online: www.euractiv.com/section/data-protection/news/ why-the-eu-leads-in-digital-regulation-but-lags-in-digital-innovation/

Komaitis, Konstantinos - Justin Sherman: US and EU tech strategy aren't as aligned as you think. Brookings Tech Stream, 2021. május 11. Online: www.brookings.edu/ techstream/us-and-eu-tech-strategy-arent-as-aligned-as-you-think/

Langvardt, Kyle: Regulating Online Content Moderation. Georgetown Law Journal, 106. (2017), 5. 1353-1388. Online: https://doi.org/10.2139/ssrn.3024739

Larger, Thibault: Italy competition watchdog opens probe into Amazon, adding to EU list. Politico, 2019. április 16. Online: www.politico.eu/article/italy-competitionwatchdog-opens-probe-into-amazon-adding-to-eu-list/

Madiega, Tambiama: Digital sovereignty for Europe. European Parliamentary Research Service, PE 651.992 - July 2020.

Madiega, Tambiama: Digital services act. European Parliamentary Research Service, PE 689.357 - March 2021.

Modrall, Jay: Google/Fitbit - The EU Commission Misses a Step. Kluwer Competition Law Blog, 2021. június 17. Online: http://competitionlawblog.kluwercompetitionlaw. com/2021/06/17/google-fitbit-the-eu-commission-misses-a-step/

OECD: What is BEPS? (é. n.). Online: www.oecd.org/tax/beps/about/

Opinion 4/2017 of the European Data Protection Supervisor on the Proposal for a Directive on certain aspects concerning contracts for the supply of digital content. Online: https://edps.europa.eu/sites/edp/files/publication/17-03-14_opinion_digital_content_en.pdf

Parry, Jacob: MEPs push for rules that allow EC to 'breakup' offenders - IMCO, 2021. január 28. Online: https://app.parr-global.com/intelligence/view/intelcms-2ng9mg?utm source $=$ Notifications\&utm_medium $=$ Email\&utm_campaign=Alert\&utm_term $=-$ 5bad06eca3fa340018bd26b6\&ssouid=ABADDE3C-90A9-4069-AC3C-FCF30B $60 C 671$ 
Petropoulos, Georgios: The EU's Digital Markets Act (DMA). Competition Policy International, 2021. május 9. Online. www.competitionpolicyinternational.com/the-eusdigital-markets-act/

Poitiers, Niclas Frederic - Dennis Görlich: Geopolitical Aspects of Digital Trade. European Union, 2020. Online: www.europarl.europa.eu/RegData/etudes/IDAN/2020 /653616/EXPO_IDA(2020)653616_EN.pdf

Posner, Eric A. - E. Glen Weyl: Radical Markets. Princeton University Press, 2018. Online: https://doi.org/10.23943/9781400889457

Rigó Csaba Balázs - Tóth András: A digitális szolgáltatási adó szimbolikus jelentősége és annak gyakorlati következményei. Pénzügyi Szemle, 65. (2020), 4. 516-530. Online: https://doi.org/10.35551/PSZ_2020_4_5

Robertson, Adi: European lawmakers asked Mark Zuckerberg why they shouldn't break up Facebook. The Verge, 2018. május 22. Online: www.theverge.com/2018 /5/22/17380982/mark-zuckerberg-european-parliament-meeting-monopoly-antitrust-breakup-question

Schaake, Marietje: How democracies can claim back power in the digital world. MIT Technology Review, 2020. szeptember 29. Online: www.technologyreview.com/2020 /09/29/1009088/democracies-power-digital-social-media-governance-tech-companies-opinion/

Scherer, Matthew U.: Regulating Artificial Intelligence Systems: Risks, Challenges, Competencies, and Strategies. Harvard Journal of Law \& Technology, 29. (2016), 2. 353400. Online: https://papers.ssrn.com/sol3/papers.cfm?abstract_id=2609777

Scott, Mark - Jacopo Barigazzi: US and Europe to forge tech alliance amid China's rise. Politico, 2021. június 9. Online: www.politico.eu/article/eu-us-trade-tech-counciljoe-biden-china/

Stigler Committee on Digital Platforms Final Report. Chicago Booth, 2019. szeptember 16. Online: www.chicagobooth.edu/research/stigler/news-and-media/committee-on-digital-platforms-final-report

Stolton, Samuel: LEAK: Commission in bid for EU data sovereignty with digital decade targets. Euractive, 2021. március 8. Online: www.euractiv.com/section/digital/news/ leak-commission-in-bid-for-eu-data-sovereignty-with-digital-decade-targets/

Tepper, Jonathan - Denise Hearn: The Myth of Capitalism. Monopolies and the Death of Competition. Wiley, 2019.

Tirole, Jean: Telecommunications and competition. In Pierre Buigues - Patrick Rey (szerk.): The Economics of Antitrust and Regulation in Telecommunications. Edward Elgar Publishing, 2004. Online: https://doi.org/10.4337/9781843769767.00029

Tirole, Jean: Competition and the Industrial Challenge for the Digital Age. 2020. április 3. Online: www.tse-fr.eu/sites/default/files/TSE/documents/doc/by/tirole/competition_and_the_industrial_challenge_april_3_2020.pdf

Tørsløv, Thomas - Ludvig Wier - Gabriel Zucman: The Missing Profits of Nations: 2017 Figures. 2019. Online: https://doi.org/10.3386/w24701

Tóth András: A mesterséges intelligencia szabályozásának paradoxonja és egyes jogi vonatkozásainak alapvető kérdései. Infokommunikáció és Jog, (2019), 2. 3-9. Online: https://infojog.hu/toth-andras-a-mesterseges-intelligencia-szabalyozasanak-paradoxonja-es-egyes-jogi-vonatkozasainak-alapveto-kerdesei-2019-2-73-3-9-o/ 
Twomey, Paul: Addressing Market Failures to improve the health of the Digital Infrastructure. T20 Policy Brief, 2017. Online: www.g20-insights.org/policy_briefs/addressing-market-failures-improve-health-digital-infrastructure/

United Nations: Digital Economy Report 2019. Online: https://unctad.org/webflyer/digital-economy-report-2019

Unlocking Digital Competition. Report of the Digital Competition Expert Panel. 2019. Online: https://assets.publishing.service.gov.uk/government/uploads/system/uploads/attachment_data/file/785547/unlocking_digital_competition_furman_review_web.pdf

Valero, Jorge: The EU's digital tax is dead, long live the OECD's plans. Euractive, 2019. március 8. Online: www.euractiv.com/section/economy-jobs/news/the-eusdigital-tax-is-dead-long-live-the-oecds-plans/

Versluis, Esther - Marjolein van Asselt - Tessa Fox - Anique Hommels: Calculable Risks? An Analysis of the European Seveso Regime. In Morag Goodwin - Bert-Jaap Koops - Ronald Leenes (szerk.): Dimension of Technology Regulations. Wolf Legal Publishers, 2010. 264.

Vig Zoltán: The Regulation of Screening of Foreign Direct Investments in the European Union. Pro Futuro, 10. (2021), 4. 9-24. Online: https://doi.org/10.26521/profuturo/2020/4/9463

Vincent, James: Obama accuses EU of attacking American tech companies because it ,can't compete'. The Verge, 2015. február 17. Online: www.theverge.com/2015/2 /17/8050691/obama-our-companies-created-the-internet

Viscusi, W. Kip - Joseph E. Harrington - John M. Vernon: Economics of Regulation and Antitrust. $4^{\text {th }}$ Edition. MIT Press Books, 2005.

Wiener, Jonathan B.: The regulation of technology, and the technology of regulation. Technology in Society, 26. (2004), 2-3. 483-500. Online: https://doi.org/10.1016/j. techsoc.2004.01.033

The world's most valuable resource is no longer oil, but data. The Economist, 2017. május 6. Online: www.economist.com/leaders/2017/05/06/the-worlds-most-valuable-resource-is-no-longer-oil-but-data

Ződi Zsolt: Az USA Igazságügyi Minisztériumának keresete a Google ellen - a versenyjog dilemmái a platformgazdaságban. Gazdaság és Jog, 28. (2020), 10. 6-8.

\section{Jogi források}

Az Európai Bizottság javaslata: Az Európai Parlament és a Tanács rendelete a mesterséges intelligenciára vonatkozó harmonizált szabályok (a mesterséges intelligencia törvény) megállapításáról és egyes Uniós jogalkotási aktusok módosításáról, Brüszszel, 2021.4.21., COM(2021) 206 végleges 2021/0106(COD) \{SEC(2021) 167 végleges $\}$ - \{SWD(2021) 84 végleges $\}-\{\operatorname{SWD}(2021) 85$ végleges $\}$

Az Európai Parlament és a Tanács (EU) 2016/679 rendelete (2016. április 27.) a természetes személyeknek a személyes adatok kezelése tekintetében történő védelméről és az ilyen adatok szabad áramlásáról, valamint a 95/46/EK rendelet hatályon kívül helyezéséről (általános adatvédelmi rendelet: GDPR) 
Az Európai Parlament és a Tanács (EU) 2018/1807 rendelete (2018. november 14.) a nem személyes adatok Európai Unióban való szabad áramlásának keretéről

Az Európai Parlament és a Tanács (EU) 2018/1807 rendelete a nem személyes adatok Európai Unióban való szabad áramlásának keretéről

Az Európai Parlament és a Tanács 715/2007/EK rendelete (2007. június 20. ) a könnyű személygépjármúvek és haszongépjárművek (Euro 5 és Euro 6) kibocsátás tekintetében történő típusjóváhagyásáról és a járműjavítási és -karbantartási információk elérhetőségéről

Az Európai Parlament és a Tanács (EU) 2015/2366 irányelve (2015. november 25.) a belső piaci pénzforgalmi szolgáltatásokról és a 2002/65/EK, a 2009/110/EK és a 2013/36/EU irányelv és a 1093/2010/EU rendelet módosításáról, valamint a 2007/64/EK irányelv hatályon kívül helyezéséről

Az Európai Parlament és a Tanács (EU) 2019/1 irányelve (2018. december 11.) a tagállami versenyhatóságok helyzetének a hatékonyabb jogérvényesítés céljából történő megerősítéséről és a belső piac megfelelő működésének biztosításáról

Az Európai Parlament és a Tanács (EU) 2019/1024 irányelve (2019. június 20.) a nyílt hozzáférésű adatokról és a közszféra információinak további felhasználásáról

Az Európai Parlament és a Tanács (EU) 2019/770 irányelve (2019. május 20.) a digitális tartalom szolgáltatására és digitális szolgáltatások nyújtására irányuló szerződések egyes vonatkozásairól (EGT-vonatkozású szöveg.)

Belgian Competition Authority, Dutch Authority for Consumers \& Markets, and Luxembourg Conseil de la Concurrence, Joint memorandum on challenges faced by competition authorities in a digital world (2019). Online: www.belgiancompetition.be/en/ about-us/publications/joint-memorandum-belgian-dutch-and-luxembourg-competition-authorities

C-311/18, Data Protection Commissioner v Facebook Ireland Ltd ECLI:EU:C:2020:559

Case M.9660 - Google/Fitbit

CMA: Online platforms and digital advertising. Market study final report (2020. július 1.)

Commission Decision of 18.7.2018 relating to a proceeding under Article 102 of the Treaty on the Functioning of the European Union (the Treaty) and Article 54 of the EEA Agreement (AT.40099 - Google Android)

Commission Decision of 27.6.2017 relating to proceedings under Article 102 of the Treaty on the Functioning of the European Union and Article 54 of the Agreement on the European Economic Area (AT.39740 - Google Search (Shopping))

COMP/M.4731 - Google/DoubleClick

COMP/M.7217 - Facebook/Whatsapp

European Commission: Proposal for a Regulation of the European Parliament and of The Council on European data governance (Data Governance Act) COM(2020) 767 final (2020. november 25.). Online: https://eur-lex.europa.eu/legal-content/EN/TXT/? uri=CELEX\%3A52020PC0767

European Commission: Proposal for a Regulation of the European Parliament and of The Council on a Single Market For Digital Services (Digital Services Act) and amending Directive 2000/31/EC COM(2020) 825 final (2020. december 15.). Online: https:// eur-lex.europa.eu/legal-content/en/TXT/?uri=COM\%3A2020\%3A825\%3AFIN

Európai Tükör 2021/2. 
Javaslat a Tanács Irányelve az egyes digitális szolgáltatások nyújtásából származó bevételek után fizetendő digitális szolgáltatási adó közös rendszeréről $\{\operatorname{SWD}(2018) 81\}-\{\operatorname{SWD}(2018)$ 82\} Brüsszel, 2018.3.21. COM(2018) 148 végleges 2018/0073 (CNS)

Proposal for a Regulation of the European Parliament and of the Council on contestable and fair markets in the digital sector (Digital Markets Act) COM(2020) 842 final (2020. december 15.). Online: https://eur-lex.europa.eu/legal-content/en/TXT/?uri=COM\%3A2020\%3A842\%3AFIN

Regulation (EU) 2019/452 of the European Parliament and of the Council of 19 March 2019 establishing a framework for the screening of foreign direct investments into the Union

Regulation (EU) 2019/881 of the European Parliament and of the Council of 17 April 2019 on ENISA (the European Union Agency for Cybersecurity) and on information and communications technology cybersecurity certification and repealing Regulation (EU) No 526/2013 (Cybersecurity Act) Online: https://eur-lex.europa.eu/ legal-content/EN/TXT/?uri=uriserv:OJ.L_.2019.151.01.0015.01.ENG

A Tanács 139/2004/EK rendelete (2004. január 20.) a vállalkozások közötti összefonódások ellenőrzéséről (az EK összefonódás-ellenőrzési rendelete) EGT vonatkozású szöveg Online: https://eur-lex.europa.eu/legal-content/HU/ALL/?uri=celex \%3A32004R0139 